Check for updates

Cite this: RSC Adv., 2021, 11, 17116

\title{
Recent updates on the bioactive compounds of the marine-derived genus Aspergillus $\dagger$
}

\author{
Raha Orfali, ${ }^{a}$ Mahmoud A. Aboseada, ${ }^{b}$ Nada M. Abdel-Wahab, ${ }^{c}$ \\ Hossam M. Hassan, (D) e Shagufta Perveen, (D) ${ }^{a}$ Fuad Ameen, ${ }^{f}$ Eman Alturki ${ }^{a}$ \\ and Usama Ramadan Abdelmohsen (D)*cd
}

\begin{abstract}
The genus Aspergillus is widely distributed in terrestrial and marine environments. In the marine environment, several Aspergillus species have proved their potential to produce a plethora of secondary metabolites including polyketides, sterols, fatty acids, peptides, alkaloids, terpenoids and miscellaneous compounds, displaying a variety of pharmacological activities such as antimicrobial, cytotoxicity, antiinflammatory and antioxidant activity. From the beginning of 2015 until December 2020, about 361 secondary metabolites were identified from different marine Aspergillus species. In our review, we highlight secondary metabolites from various marine-derived Aspergillus species reported between January 2015 and December 2020 along with their biological potential and structural aspects whenever applicable.
\end{abstract}

Received 19th February 2021

Accepted 9th April 2021

DOI: 10.1039/d1ra01359a

rsc.li/rsc-advances

bioactivities and chemical structures of 512 marine metabolites

\section{Introduction}

Of all marine-derived fungi, the genus Aspergillus has gained the most awareness since it accounted for about 31 percent of natural marine fungal products from 2010 to $2013 .^{1}$ Marine Aspergillus strains produce metabolites of different chemical structures, including fatty acids, polyketides, sterols, alkaloids, terpenoids, peptides, butenolides, and others, with a range of bioactivities, including antimicrobial, cytotoxicity, insecticidal, neuroprotective, and antioxidant activity. Plinabulin, a dehydrodiketopiperazine halimide analog, was terminated in phase II trials and also obtained a phase III review in 2015 for the treatment of non-small cell lung cancer (advanced metastatic) and now has become FDA-approved. ${ }^{1-3}$ Reviewing the available literature concerning the genus Aspergillus marine-derived metabolites, a study was found demonstrating the

${ }^{a}$ Department of Pharmacognosy, College of Pharmacy, King Saud University, P. O. Box 22452, Riyadh 11495, Kingdom of Saudi Arabia. E-mail: rorfali@ksu.edu.sa; shakhan@ksu.edu.sa; emalturki@ksu.edu.sa

${ }^{b}$ Department of Pharmacognosy, Faculty of Pharmacy, Nahda University, Beni-Suef 62513, Egypt

'Department of Pharmacognosy, Faculty of Pharmacy, Minia University, 61519 Minia, Egypt.E-mail: usama.ramadan@mu.edu.eg; nada_abdelwahabo7@yahoo.com; Fax: +20-86-2369075; Tel: +20-86-2347759

${ }^{d}$ Department of Pharmacognosy, Faculty of Pharmacy, Deraya University, 61111 New Minia, Egypt

${ }^{e}$ Department of Pharmacognosy, Faculty of Pharmacy, Beni-Suef University, Beni-Suef 62513, Egypt

${ }^{f}$ Department of Botany \& Microbiology, College of Science, King Saud University, Riyadh, Saudi Arabia.E-mail: FuadAmeen@ksu.edu.sa

$\dagger$ Electronic supplementary information (ESI) available. See DOI: 10.1039/d1ra01359a of Aspergillus origins between January 1992 and December 2014. ${ }^{1}$ Herein, the present study surveys most of the bioactive principles isolated from the marine-derived genus Aspergillus from 2015 till December 2020 and their abundance along with pharmacological potential.

\section{Pharmacological activities}

Over 5000 bioactive compounds have been identified from marine sources over the last few decades, showing various biological activities, including antibacterial, antitumor, anticoagulant, antifungal, anti-inflammatory and antiviral activities. ${ }^{4,5}$ Many of these metabolites are documented for their exceptional potencies that could be due to the need to resolve dilution of allelochemicals in seawater. ${ }^{6,7}$ Natural products extracted from marine Aspergillus spp. have been primarily linked to antimicrobial and cytotoxic bioactivities. ${ }^{8}$

\section{Anticancer activity}

Violaceimides A-B (1 and 2), two methylsuccinimide-based sulfur-bearing compounds, were isolated from Aspergillus violaceus WZXY-m64-17, a sponge-associated fungal strain. Both compounds exerted selective inhibition against the human leukemia U937 growth with $\mathrm{IC}_{50}$ values of $5.3 \pm 0.4$ and $1.8 \pm 0.6$ $\mu \mathrm{M}$, respectively and also against human colorectal cancer cell HCT-8 with $\mathrm{IC}_{50}$ values of $1.5 \pm 0.28$ and $2.51 \pm 0.51 \mu \mathrm{M}$, respectively. ${ }^{9}$

An enzyme with anticancer potential named L-asparaginase (LA) was purified and characterized from the marine-derived Aspergillus niger. This enzyme displayed impressive 
antiproliferative activity against different lines of cancer cells, including U87MG, A549, HepG2, bone marrow-derived chronic myeloid leukemia cells and JURKAT E6 with $\mathrm{IC}_{50}$ values of 0.399, 0.375, 0.204, 0.2 and $0.22 \mathrm{U} \mathrm{mL}^{-1}$, respectively. ${ }^{10}$ Asperterreusine A (3), a dihydrobenzofuran derivative, was purified from Aspergillus terreus [CFCC 81836], a marine-derived fungus. This benzofuran metabolite was investigated for its cytotoxic activities against diverse human cancer cell lines (SW-480 HL60, A-549, SMMC-7721, and MCF-7). It showed cytotoxicity against SW-480 and HL-60 cancer cell lines with $\mathrm{IC}_{50}$ values of 25.7 and $15.3 \mu \mathrm{M}$, respectively. ${ }^{11}$

Highly oxygenated meroterpenoids namely, terreustoxin A (4) and terretonin (5), were isolated from the Antarctic fungus Aspergillus terreus. These meroterpenoids displayed a proliferation inhibition of Con A-induced murine $\mathrm{T}$ cells at the concentration of $10 \mu \mathrm{M} \cdot{ }^{12}$ A meroterpenoid, terretonin $\mathrm{C}(6)$, a halogenated furanone, rubrolide $S$ (7) and a butenolide derivative, 5-[(3,4-dihydro-2,2-dimethyl-2H-1-benzopyran-6-yl)methyl]-3-hydroxy-4(4-hydroxyphenyl)-2(5H)-furanone (8), were isolated from the Aspergillus terreus OUCMDZ-2739, after chemical-epigenetic culture with $10 \mathrm{mM}$ trichostatin A (TSA). For rubrolide S (7) against K562 cells, butenolide derivative (8) against $\mathrm{K} 562$ and MCF-7 cells and terretonin C (6) against MCF7 cancer cell line with $\mathrm{IC}_{50}$ values of $9.5,13.0,10.1$ and $8.5 \mu \mathrm{M}$, respectively, cytotoxicity was observed. ${ }^{13}$

A cryptic 3,4-dihydronaphthalen-(2H)-1-one (1-tetralone) derivative, aspvanicin B (9) and a xanthone, namely sterigmatocystin (10) were obtained from the marine-derived Aspergillus versicolor KU258497 co-cultured with the bacterium Bacillus subtilis 168 trpC2. Both metabolites were assessed for their cytotoxic activities, showing moderate $\left(\mathrm{IC}_{50}=22.8 \mu \mathrm{M}\right)$ for aspvanicin $\mathrm{B}(9)$ to strong cytotoxic activity $\left(\mathrm{IC}_{50}=\right.$ of $\left.2.2 \mu \mathrm{M}\right)$ for xanthone derivative (10) against the mouse lymphoma cell line L5178. ${ }^{14}$

Marine-derived fungus Aspergillus terreus extract was subjected to a chemical study yielding two butenolide derivatives, named (+)-3', $3^{\prime}$-di-(dimethylallyl)-butyrolactone II (11) and versicolactone $\mathrm{B}$ (12). The two butenolides were evaluated against HCC1806, PANC-1, HepG2, HT-29 and BEAS-2B cancer cell lines, exhibiting potent cytotoxic activity against PANC-1 cancer cell line, with $\mathrm{IC}_{50}$ values of 5.3 and $9.4 \mu \mathrm{M}$, respectively. Morphological features of apoptosis were observed in 11 and 12treated PANC-1 cells, including membrane blebbing, apoptotic body formation, nuclear condensation and cell shrinkage. Analysis of the cell cycle using propidium iodide staining showed that (+)-3', $3^{\prime}$-di-(dimethylallyl)-butyrolactone II (11) inhibits the proliferation of PANC-1 cells through the S phase and G2/M arrest induction, while versicolactone B (12) could inhibit the induction of PANC-1 cells through the $\mathrm{S}$ phase arrest. Treatment with both metabolites substantially induced apoptosis of PANC- 1 cells indicated by flow cytometric study. ${ }^{\mathbf{1 5}}$

Fermentation of the mangrove-derived fungus Aspergillus sp. $\mathrm{AV}-2$ on solid rice medium followed by chemical investigation led to the purification of prenylated benzaldehyde derivatives, named tetrahydroauroglaucin (13), isotetrahydroauroglaucin (14), isodihydroauroglaucin (15), flavoglaucin (16) and 2- $\left(2^{\prime}, 3-\right.$ epoxy-1', $3^{\prime}, 5^{\prime}$-heptatrienyl)-6-hydroxy-5-(3-methyl-2-butenyl) benzaldehyde (17). All of them were assessed for their antiproliferative activity against Caco- 2 cell lines, exhibiting strong inhibition, where flavoglaucin (16) revealed the most potent cytotoxicity with $\mathrm{IC}_{50}$ of $2.87 \mu \mathrm{M}^{16}$ A biphenyl derivative, diorcinol (18) and an anthraquinone, versicolorin B (19) were isolated from a marine-derived fungus Aspergillus versicolor ZZ761. These compounds had anti-proliferative activity against human U251 and glioma U87MG cells with $\mathrm{IC}_{50}$ values of 6.2 and $4.4 \mu \mathrm{M}$ and 30.5 and $11.3 \mu \mathrm{M}$, respectively. ${ }^{17}$

From the deep-sea-derived fungus Aspergillus candidus, $p$ terphenyl derivates were isolated, namely terphenyllin (20) and prenylterphenyllin (21). The two metabolites were tested for in vitro antitumor activities, showing potent anti-proliferative effect against four cancer cells of Eca-109, Hela, PANC-1 and Bel-7402, with $\mathrm{IC}_{50}$ values varying between $5.5 \mu \mathrm{M}$ and $9.4 \mu \mathrm{M} .^{18}$ 3,4-Dimethoxyphenyl $\alpha$-D-ribofuranoside (22), a phenolic glycoside, together with four indole-diketopiperazine alkaloids, namely echinulin (23), tardioxopiperazine B (24), neochinulin D (25), and variecolorin $\mathrm{O}$ (26) and nucleotides named uracil (27) and adenine (28), were isolated from the marine-derived endophytic fungus Aspergillus amstelodami (white beans culture). The antimelanogenic activity of the compounds isolated has been investigated. In B16 melanoma cancer cells, these compounds selectively repressed melanin output (arbutin was used as a positive control). Their IC $_{50}$ values were $30.8 \pm$ 5.57 (22), $38.5 \pm 6.08$ (23), $52.6 \pm 6.64$ (24), $98.0 \pm 1.16$ (25), $100.4 \pm 3.05$ (26), $112.0 \pm 0.22$ (27) and $144.7 \pm 2.35 \mu \mathrm{M}$ (28), respectively, compared to $151.7 \pm 1.27 \mu \mathrm{M}$ for arbutin. ${ }^{19}$

Epicoccolides A, B $(\mathbf{2 9}, \mathbf{3 0})$ and NC3B (31), three polyoxygenated polyketides, were purified from Aspergillus micronesiensis, a marine-derived fungus via combined chromatographic methods. The three compounds were evaluated for their cytotoxic activity against LU-1, Hep-G2 and Vero cells, displaying significant cytotoxic bioactivities with $\mathrm{IC}_{50}$ values ranging between 3.97 and 4.71 $\mu \mathrm{g} \mathrm{mL}{ }^{-1}$ (the $\mathrm{IC}_{50}$ values of the positive control, ellipticine $=0.29$ $\left.0.31 \mu \mathrm{g} \mathrm{mL}{ }^{-1}\right) .{ }^{20}$ A diphenyl derivative, geodin (32) was isolated from Aspergillus sp. derived from the soft coral Sinularia sp. This metabolite has been tested for its cytotoxic activity against different lines of human cancer cells, including NCI-H460 large cell lung cancer cells, BT474 breast cancer cells, K562 chronic myelogenous leukemia cells, H-1975 non-small cell lung cancer cells, A549 lung cancer cells and DU1455 prostate cancer cells. Geodin (32) displayed substantial cytotoxic activity with $\mathrm{IC}_{50}$ values of 9.22, 8.88, 11.14, 9.96, 11.05 and $14.44 \mu \mathrm{M}$, respectively, against all cancer cells (positive control was staurosporine). ${ }^{21}$ A xanthone named AGI-B4 (33) was obtained from a deep sea-derived fungus Aspergillus sydowii C1-S01-A7. This xanthone remarkably exhibited selectively cytotoxic activity against A549 cell line with low $\mathrm{IC}_{50}$ value $(<10 \mu \mathrm{M})$ and the strongest cytotoxic activities for both HepG2 and A549 with $\mathrm{IC}_{50}$ values of $30.7 \pm 0.9$ and $8.1 \pm 1.3$, respectively. ${ }^{22}$ Seco-anthraquinone, chlorotrypacidin (34), was isolated from Aspergillus versicolor, a gorgonian-derived fungus, the South China Sea. Chlorotrypacidin (34) displayed cytotoxic activity against various tumor cell lines HL-60, HCT-116 and HepG2, with $\mathrm{IC}_{50}$ values of $18.5,17.6$ and $15.2 \mu \mathrm{M}$, respectively. ${ }^{23}$

Seven prenylated $p$-terphenyls, prenylterphenyllins F-J (3539) and prenylcandidusins $\mathrm{E}$ and $\mathrm{G}(\mathbf{4 0}, \mathbf{4 1})$ were isolated from 
a mangrove endophytic fungus, Aspergillus candidus LDJ-5. All these compounds are cytotoxic against SH-SY5Y, MGC-803, HCT-116, BEL-7402, A549, L-02, HeLa and U87 cells, with values in the $\mathrm{IC}_{50}$ range between 0.4 and $24.4 \mu \mathrm{M} .^{24} \mathrm{~A}$ bis-indolyl benzenoid, petromurin C (42), was purified from the Aspergillus candidus KUFA0062 marine fungus (culture extract) derived from the marine sponge Epipolasis sp. Petromurin C (42) caused premature autophagy followed by apoptosis via mitochondrial stress concomitant with the intrinsic cell death activation pathway and Mcl-1 downregulation in FLT3-ITD mutated MV411 cells. Beside, petromurin $\mathrm{C}(\mathbf{4 2})$ was synergized with gilteritinib (FLT3 inhibitor clinically used) at subtoxic concentrations. $^{25}$

Prenylxanthones, A (43), C (44) and F (45), aspergixanthones, were isolated from the marine fungus Aspergillus sp. ZA-01. These prenylxanthones were evaluated for their cytotoxic activity. Aspergixanthones A (43) and F (45) demonstrated cytotoxicity against the neural cell line A-549 with $\mathrm{IC}_{50}$ values of 1.8 and $1.1 \mu \mathrm{M}$ respectively. Aspergixanthones $\mathrm{C}$ (44) and F (45) showed broad-spectrum cytotoxicities against five tumor cell lines, MDA-MB-231, MCF-7, MGC-803 and HeLa A-549, with values $\left(\mathrm{IC}_{50}\right)$ ranging from 1.1 to $9.8 \mu \mathrm{M}^{26}$ Five prenylated indole alkaloids, 17-O-ethylnotoamide M (46), (-)-notoamide B (47), notoamides C (48) and M (49), and sclerotiamide (50), were isolated from of marine-derived fungi Aspergillus sulphureus KMM 4640 after co-culturing with Isaria felina KMM 4639. Notoamide $\mathbf{M}$ (49) caused the most inhibition against human prostate cancer cells 22Rv1 (colony formation) at a noncytotoxic concentration of $10 \mu \mathrm{M}$, whilst other alkaloids caused inhibition at $100 \mu \mathrm{M} \cdot{ }^{27}$

An indole alkaloid, misszrtine A (51), was isolated from marine sponge-derived fungus Aspergillus sp. SCSIO XWS03F03. It demonstrated a strong antagonistic action on the cancer cell lines of the HL60 leukemia $\left(\mathrm{IC}_{50}=3.1 \mu \mathrm{M}\right)$ and $\mathrm{LNCaP}$ prostate $\left(\mathrm{IC}_{50}=4.9 \mu \mathrm{M}\right)$, implying that the functional group on misszrtine A (51) indole nitrogen has a significant impact on its cytotoxicity, which offers a means of understanding the structure-activity relationship. ${ }^{28}$

A diketopiperazine alkaloid, mactanamide (52), was isolated from the marine sponge Stylissa sp.-derived fungus Aspergillus flocculosus collected in Vietnam. The isolated compound was evaluated for anti-proliferation activity, and a powerful effect of non-cytotoxic suppression on osteoclast differentiation was shown. Such suppression effects were demonstrated by osteoclast differentiation-induced receptor activation of the nuclear factor ${ }_{\mathrm{k}} \mathrm{B}$ ligand (RANKL). ${ }^{29}$ Chrysophanic acid anthraquinone (53), together with four bis-indolyl benzenoids, asterriquinol D dimethyl ether (54), kumbicin A (55), D (56) and $(3 S, 6 S)-3,6$ dibenzylpiperazine-2,5-dione (57), were isolated from the cultures of Aspergillus candidus KUFA 0062, a marine spongeassociated fungus. These compounds were tested against several cancer cell lines for cytotoxicity: T98G, U-251, HCT116, A549, A 375, MCF-7, HT29 and HepG2, demonstrating cytotoxicity against all cancer cell lines tested. ${ }^{30}$

Versixanthones $\mathrm{N}-\mathrm{O}(\mathbf{5 8}, \mathbf{5 9})$, two tetrahydroxanthone dimers, were isolated from Aspergillus versicolor HDN1009 (mangrove-derived fungus). These dimers exhibited extensive cytotoxicities against different cancer cell lines (K562, HL-60, HO-8910, MGC803 and $\mathrm{H} 1975$ ), with $\mathrm{IC}_{50}$ values ranging between $1.7 \mu \mathrm{M}$ and $16.1 \mu \mathrm{M} .^{31}$

An aspochalasin, tricochalasin D (60) has been isolated from the Aspergillus sp. found in the gut of Ligia oceanica, a marine isopod. It was evaluated for cytotoxic effect against prostate cancer cell line (PC3), showing strong activity with $\mathrm{IC}_{50}$ value of $11.14 \mu \mathrm{M}^{32}$

Cordyol C-3-O- $a$-D-ribofuranoside (61), 7-ethyldiorcinol (62), 3-hydroxydiorcinol (63), glyceryl diorcinolic acid (64), cordyol C (65), and aspergilol E (66), are six diphenyl ethers, which were purified from the marine-derived Aspergillus sydowii (ethyl acetate extract). These diphenyl derivatives were assayed for their cytotoxic effects against different cancer cell lines, including U937, 4T1, HT-29, PC3, HL-60, K562, A549 and NCI$\mathrm{H} 460$, exhibiting selective cytotoxicity with $\mathrm{IC}_{50}$ values varying between $3.36 \pm 0.68$ and $23.03 \pm 1.345$ against multiple cancer cell lines. ${ }^{33}$ The initial fermentation of the fungus Aspergillus ochraceus cultivated from the Mediterranean sponge Agelas oroides on solid rice medium yielded a naphthoquinone derivative named viomellein (67) and phenylalanine derivative, namely ochratoxin B (68). These derivatives demonstrated a significant cytotoxic impact against human ovarian carcinoma (A2780) cells with $\mathrm{IC}_{50}$ values of 5.0 and $3.0 \mu \mathrm{M}$, respectively. ${ }^{34}$

Nine sesterterpenes, 14,15-dehydro-6-epi-ophiobolin K (69), 14,15-dehydro-ophiobolin K (70), 14,15-dehydro-6-epi-ophiobolin G (71), 14,15-dehydro-ophiobolin G (72), 14,15-dehydro-(Z)14-ophiobolin G (73), 6-epi-ophiobolin C (74), ophiobolin C (75), 6-epi-ophiobolin N (76), and ophiobolin N (77), were isolated from Aspergillus flocculosus, a marine fungus originating from the seaweed Padina sp., Vietnam. For cytotoxic effect against various cancer cell lines, NUGC-3, HCT-15, NCI-H23, ACHN, MDA-MB-231 and PC-3, all isolated ophiobolins were investigated, showing potent cytotoxicities with $\mathrm{GI}_{50}$ values varying between 0.14 and $2.01 \mu \mathrm{M} .{ }^{35}$ Ochrazepines A-D (78-81), four circumdatin-aspyrone conjugates, were isolated from the coralassociated Aspergillus ochraceus strain LCJ11-102. Ochrazepine A (78) exhibited cytotoxic activity against numerous human cancer cell lines while ochrazepines B (79) and D (81) selectively inhibited the human glioblastoma U251 cell line and ochrazepines $\mathrm{C}(\mathbf{8 0})$ was active against the cell lines of human rhabdomyoma A673, human glioblastoma U87, and human liver cancer Hep3B, with $\mathrm{IC}_{50}$ values of $2.5-11.3 \mu \mathrm{M} .^{36}$

A hydroxyl pyrrolidine derivative, preussin (82), was isolated from Aspergillus candidus KUFA 0062, a marine spongeassociated fungus. This pyrrolidine derivative was evaluated for its antiproliferative and cytotoxic effects in breast cancer cells (SKBR3, MCF7, and MDA-MB-231), and in MCF12A, a nontumor cell line. Analysis of cell morphology for ki67 and caspase-3 was performed as well as 3D (multicellular aggregates) and 2D (monolayer) cultures tests, using various assays. This metabolite affected cell proliferation and viability in cultures of both 3D and 2D in all cell lines tested. 3D culture cells were less responsive and preussin-exposed cells morphological study revealed apoptosis, which was confirmed by caspase-3 immunohistochemistry. ${ }^{37}$ In the course of chemical characterization of the marine-derived fungus Aspergillus flavus 
<smiles>C#CC1CC(=O)N(C(CSCC(O)C(=O)O)C(=O)OC)C1=O</smiles><smiles>COC(=O)C(O)CSCC(C(=O)OC)N1C(=O)CC(C)C1=O</smiles><smiles>COc1cc2c(c(OC)c1C(=O)O)OC[C@H]2O</smiles>

(3)

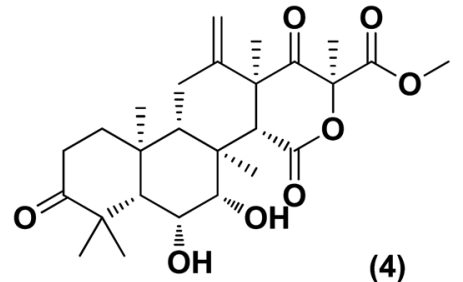

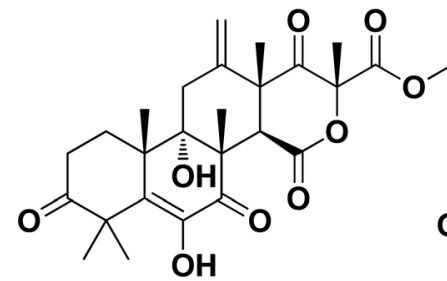

(5)

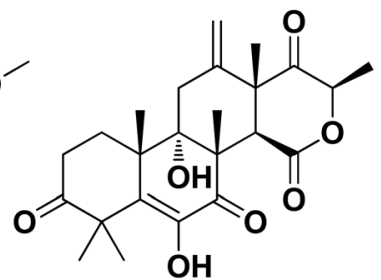

(6)<smiles>CC1(C)CCc2cc(/C=C3\OC(=O)C=C3c3ccc(O)cc3)ccc2O1</smiles><smiles>CC1(C)CCc2cc(CC3OC(=O)C(O)=C3c3ccc(O)cc3)ccc2O1</smiles><smiles>COc1cc(O)c2c(c1O)[C@H](OC)[C@H](CC(C)=O)CC2=O</smiles>

(9)<smiles>COc1cc2c(c3oc4cccc(O)c4c(=O)c13)[C@@H]1C=CO[C@@H]1O2</smiles>

(10)<smiles>COC(=O)[C@]1(Cc2ccc(O)c(CC=C(C)C)c2)OC(=O)C(O)=C1c1ccc(O)c(CC=C(C)C)c1</smiles>

(11)<smiles>C=C(C)[C@@H]1CC=C(C)[C@@H](O)CC[C@H]2C[C@H]1OC2=O</smiles>

(12)<smiles>C/C=C/C=C/CCc1c(O)cc(CC=C(C)C)c(O)c1C=O</smiles>

(13)

(14)<smiles>CCCCCCCc1c(O)cc(CC=C(C)C)c(O)c1C=O</smiles><smiles>C/C=C/C=C/C1OC1c1ccc(CC=C(C)C)c(O)c1C=O</smiles><smiles>Cc1cc(O)cc(Oc2cc(C)cc(O)c2)c1</smiles><smiles>O=C1c2cc(O)cc(O)c2C(=O)c2c1cc1c(c2O)C2CCOC2O1</smiles>

(19)<smiles>COc1cc(-c2ccc(O)cc2)c(OC)c(O)c1-c1ccc(O)cc1</smiles>

(20)<smiles>COc1cc(-c2ccc(O)cc2)c(OC)c(O)c1-c1ccc(O)c(CC=C(C)C)c1</smiles>

Fig. 1 Chemical structure of compounds 1-21.

CF13-11, asperienes A-D (83-86), four C-6'/C-7' epimeric drimane sesquiterpenes, were isolated. These sesquiterpene esters displayed potent bioactivities towards various cell lines (MCF-7, HeLa, A549 and MGC-803) with the $\mathrm{IC}_{50}$ values ranging between 1.4 and $8.3 \mu \mathrm{M}$. Moreover, compounds A (83) and D (86) demonstrated lower toxicity towards normal GES-1 cells than $\mathrm{B}$
(84) and $\mathrm{C}(\mathbf{8 5})$, indicating greater potential for discovery as an antitumor candidate in the future. ${ }^{38}$

A prenylated diphenyl derivative named dihydrobenzofuran diphenyl ether (87) was isolated from Aspergillus tennesseensis, a marine algae-endophytic fungus. It was examined for cytotoxic activities, displaying considerable in vitro inhibitory activity 
<smiles>OC[C@H]1OC(Oc2ccc3c(c2)OCCO3)[C@H](O)[C@@H]1O</smiles><smiles>C=CC(C)(C)c1[nH]c2c(CC=C(C)C)cc(CC=C(C)C)cc2c1CC1NC(=O)[C@H](C)NC1=O</smiles><smiles></smiles><smiles>C=CC(C)(C)c1[nH]c2c(CC=C(C)C)cccc2c1C[C@H]1NC(=O)CNC1=O</smiles>

(22)<smiles>C=CC(C)(C)c1[nH]c2ccccc2c1/C=C1\NC(=O)C(C)(O)NC1=O</smiles><smiles>O=c1cc[nH]c(=O)[nH]1</smiles>

(27)<smiles>Nc1ncnc2nc[nH]c12</smiles>

(28)<smiles>Cc1c(O)c(O)c2c(c1C=O)[C@H]1O[C@@H]2Oc2c(O)c(O)c(O)c(C)c21</smiles>

(29)<smiles>Cc1c(O)c(O)c(O)c(C=O)c1-c1cc2c(C=O)c(C)c(O)c(O)c2o1</smiles>

(30)<smiles>COOC1=CC(=O)C=C(OC)C12Oc1c(cc(Cl)c(C)c1Cl)C2=O</smiles>

(34)<smiles>Cc1c(O)c(O)c(O)c2c1COC2</smiles>

(31)<smiles>COC(=O)C1=CC(=O)C=C(OC)C12Oc1c(Cl)c(C)c(Cl)c(O)c1C2=O</smiles>

(32)<smiles>COC(=O)[C@H]1c2c(oc3cc(CO)cc(O)c3c2=O)C=C[C@H]1O</smiles>

(33)<smiles>CCCC(C)(C)Oc1ccc(-c2c(OC)cc(-c3ccccc3)c(OC)c2O)cc1OC</smiles>

(36)<smiles>COc1cc(-c2cc(OC)c(OC)c(O)c2-c2ccc(O)c(O)c2)ccc1OCC=C(C)C</smiles>

(37)<smiles>COc1cc(-c2c(OC)cc(-c3ccccc3)c(OC)c2O)cc(CC=C(C)C)c1O</smiles>

(38)<smiles>COc1ccc(-c2cc(OC)c(OC)c(O)c2-c2ccc(O)c(CC=C(C)C)c2)cc1OC</smiles>

(39)

Fig. 2 Chemical structure of compounds 22-39.

against the THP-1 leukemia cell line, with an $\mathrm{IC}_{50}$ value of $7.0 \mu \mathrm{g}$ $\mathrm{mL}^{-1} \cdot{ }^{39}$ Nitrobenzoyl sesquiterpenes are rare from natural sources. 14- $O$-Acetylinsulicolide A (88), 6 $\beta, 9 \alpha$-dihydroxy-14- $p$ nitrobenzoylcinnamolide (89) and insulicolide A (90), three nitrobenzoyl sesquiterpenoids, were isolated from the marinederived fungus (Aspergillus ochraceus Jcma1F17), These sesquiterpenoidal metabolites were evaluated for their cytotoxic effects against three various carcinoma cell lines, 786-O, ACHN and OS-RC-2, cells, displaying activities with $\mathrm{IC}_{50}$ values ranging between 0.89 and $8.2 \mu \mathrm{M}$. In addition, 14-O-acetylinsulicolide A (88) induced late programmed $786-\mathrm{O}$ cells death at 
<smiles>COc1cc2c(cc1O)oc1c(OC)c(-c3ccccc3)cc(OC)c12</smiles>

(40)<smiles>C=C(C)[C@@H]1COc2c(C)cc3oc4c([C@H](OC)[C@@H](O)C(C)(C)O)ccc(O)c4c(=O)c3c2[C@H]1OC(C)=O</smiles>

(43)<smiles>C=CC(C)(C)[C@]1(C)C(=O)Nc2c1ccc1c2C=CC(C)(C)O1</smiles>

(46)<smiles>CC1(C)C=Cc2c(ccc3c2NC(=O)[C@]32[C@H](O)[C@@]34NC(=O)[C@]3(NC4=O)C(C)(C)[C@H]2O)O1</smiles><smiles>COc1cc2oc3c(OC)c(-c4cc(CC=C(C)C)c(O)c(OC)c4)cc(OC)c3c2cc1O</smiles>

(41)<smiles>COc1c(OC)c(-c2c[nH]c3cc(CC=C(C)C)ccc23)c(OC)c(OC)c1-c1c[nH]c2ccccc12</smiles><smiles>C=C(C)O[C@H]1c2c(c(C)cc3oc4c([C@H](O)[C@H](O)C(C)(C)O)ccc(O)c4c2c3=O)OCC1C(=C)C</smiles>

(44)<smiles>C=C(C)[C@H]1COc2c(C)cc3oc4c([C@H](OC)[C@H](OC(C)=O)C(C)(C)O)ccc(O)c4c(=O)c3c2[C@H]1O</smiles>

(45)<smiles>CC1(C)C=Cc2c(ccc3c2NC(=O)[C@]32C[C@@]34NC(=O)[C@@]3(CC3CCCN3C4=O)C2(C)C)O1</smiles>

(47)<smiles>C=CC(C)(C)[C@]1(C)C(=O)Nc2c1ccc1c2C=CC(C)(C)O1</smiles>

(48)<smiles>C=CC(C)(C)[C@]1(C)C(=O)Nc2c1ccc1c2C=CC(C)(C)O1</smiles>

(49)<smiles>CC(C)=CCn1cc(C[C@H](C(=O)[O-])N(C)C(=O)[C@H](O)Cc2ccccc2)c2ccccc21</smiles>

(51)<smiles>CN1C(=O)[C@@H](Cc2c(O)cccc2O)NC(=O)[C@H]1Cc1ccccc1</smiles>

(52)<smiles>Cc1cc(O)c2c(c1)C(=O)c1cccc(O)c1C2=O</smiles>

(53)<smiles>COc1c(OC)c(-c2c[nH]c3ccccc23)c(OC)c(OC)c1-c1c[nH]c2ccccc12</smiles>

(54)<smiles>COc1c(OC)c(-c2c[nH]c3ccc(O)cc23)c(OC)c(OC)c1-c1c[nH]c2ccccc12</smiles>

(55)<smiles>COC1=C(c2c[nH]c3ccccc23)C(=O)C(/C=C/C(C)C)=C(c2c[nH]c3ccc(O)cc23)C1=O</smiles>

(56)

Fig. 3 Chemical structure of compounds 40-56.

a concentration of $2 \mu \mathrm{M}$ (72 h treatment) and arrested the cell cycle at the G0/G1 phase at a concentration of $1 \mu \mathrm{M}^{40}$

Based on the characteristics of the dimeric xanthone structures, three dimeric xanthones, versixanthones G (91), H (92) and K (93) were isolated from the mangrove-derived Aspergillus versicolor fungus. These compounds showed the effects of Topo I inhibition and the most potent versixanthone $\mathrm{G}(\mathbf{9 1})$, a versixanthone $\mathrm{H}$ atropisomer (92), was assured of inhibiting Topo I- 
<smiles>O=C1N[C@H](Cc2ccccc2)C(=O)N[C@H]1Cc1ccccc1</smiles><smiles></smiles>

(57)

(58)

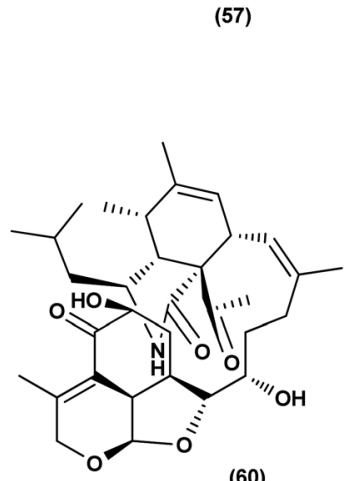<smiles>Cc1cc(O)cc(Oc2cc(C)cc(O[C@@H]3O[C@H](CO)[C@@H](O)[C@H]3O)c2O)c1</smiles>

(61)

(62)<smiles>COC(=O)[C@@]12Oc3cc(C)c(-c4ccc(O)c5c4OC(C(=O)O)(C(=O)O)[C@@H](O)[C@@H](C)CC5=O)c(O)c3C(O)=C1C(=O)CC[C@H]2C</smiles><smiles>CCCc1cc(C)cc(Oc2cc(O)cc(O)c2)c1</smiles>

(63)<smiles>Cc1cc(O)cc(Oc2cc(C)c(C(=O)O)c(CC(O)CO)c2)c1</smiles>

(64)<smiles>CCCCC[C@@H](c1c(C)cc(Oc2cc(C)cc(O)c2)cc1O)c1c(O)cc2c(c1O)C(=O)c1c(O)cc(O)cc1C2=O</smiles><smiles>COC1=C(c2c(OC)cc3cc4c(c(O)c3c2O)C(=O)O[C@H](C)C4)C(=O)c2c(cc3c(c2O)C(=O)O[C@@H](C)C3)C1=O</smiles><smiles>C[C@H]1Cc2ccc(C(=O)N[C@@H](Cc3ccccc3)C(=O)O)c(O)c2C(=O)O1</smiles>

(68)<smiles>CC(C)=C/C=C/C(C)=C1\CC[C@]2(C)C[C@@H]3C(C)=CC(=O)[C@H]3/C(C=O)=C/C[C@@H]12</smiles>

(71)<smiles>CC(C)=C/C=C/C(C)=C1\CC[C@]2(C)C[C@H]3[C@H](C(=O)C[C@]3(C)O)/C(C=O)=C/C[C@]12C</smiles>

(69)<smiles>CC(C)=C/C=C/C(C)=C1\CC[C@]2(C)C[C@@H]3C(C)=CC(=O)[C@H]3/C(C=O)=C\C[C@H]12</smiles>

(72)<smiles>CC(C)=C/C=C/C(C)=C1\CC[C@]2(C)C[C@H]3[C@H](C(=O)C[C@]3(C)O)/C(C=O)=C/C[C@]12C</smiles>

(70)

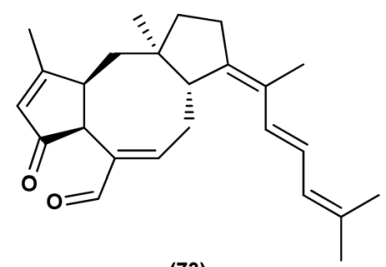

(73)

Fig. 4 Chemical structure of compounds 57-73.

mediated DNA relaxation by targeting Topo I and thus stopping the cell cycle process and causing necrosis in cancer cells. Studies of molecular docking showed that versixanthone G (91) could bind DNA through $\pi-\pi$ interaction and DNA Topo I via hydrogen bonds, forming a ternary complex. ${ }^{41}$ Ophiobolins, namely ophiobolins Z (94), K (95), O-Q (96-98), 21-epi- ophiobolin Z (99), 6-epi-ophiobolin K (100), ophiobolin G (101), 21,21-O-dihydro-6-epi-ophiobolin G (102), were isolated from the mangrove fungus Aspergillus ustus 094102. These compounds displayed cytotoxicities against the HL-60, MCF-7, MD-MBA-231, MCF/Adr, A549 and G3K human cancer cells with the $\mathrm{IC}_{50}$ values ranging between 0.6 and $9.5 \mu \mathrm{M}^{42}$ 
<smiles>CC(C)=CCC[C@@H](C)C1CC[C@]2(C)C[C@H]3C(C(=O)C[C@@]3(C)O)/C(C=O)=C\CC12</smiles>

(74)<smiles>CC(C)=C[C@@H]1C[C@@H](C)[C@]2(CC[C@@]3(C)C[C@H]4[C@@H](C(=O)C[C@]4(C)O)/C(C=O)=C/C[C@@H]32)O1</smiles>

(77)<smiles>CC(C)=CCC[C@@H](C)[C@H]1CC[C@]2(C)C[C@H]3C(C(=O)C[C@@]3(C)O)/C(C=O)=C\C[C@@H]12</smiles>

(75)<smiles>CC(C)=CCC[C@@H](C)[C@H]1CC[C@]2(C)C[C@@H]3C(C)=CC(=O)[C@H]3/C(C=O)=C/C[C@@H]12</smiles>

(76)<smiles>CC1NC(=O)c2cc(O[C@@H](C3=C[C@H](O)[C@@H](C)OC3=O)[C@@H](C)O)c(O)cc2-n2c1nc1ccccc1c2=O</smiles>

(78)<smiles>C[C@@H]1NC(=O)c2cc(O[C@@H](C3=C[C@H](O)[C@@H](C)OC3=O)[C@@H](C)O)c(O)cc2-n2c1nc1ccccc1c2=O</smiles>

(79)<smiles>CC1NC(=O)c2cc(O)c(O[C@H](C3=C[C@@H](O)[C@H](C)OC3=O)[C@H](C)O)cc2-n2c1nc1ccccc1c2=O</smiles>

(80)<smiles>C[C@H](O)[C@H](O)/C=C/C=C/C(=O)O[C@H]1C=C2COC(=O)[C@]2(O)[C@@]2(C)CCCC(C)(C)[C@H]12</smiles>

(83)<smiles>C[C@H](O)[C@H](O)/C=C/C=C/C(=O)O[C@H]1C=C2COC(=O)[C@]2(O)[C@@]2(C)CCCC(C)(C)[C@H]12</smiles>

(86)<smiles>C[C@H]1NC(=O)c2cc(O)c(O[C@@H](C3=C[C@H](O)[C@@H](C)OC3=O)[C@@H](C)O)cc2-n2c1nc1ccccc1c2=O</smiles>

(81)<smiles>CCCCCCCCCC1CC(O)C(Cc2ccccc2)N1C</smiles>

(82)<smiles>C[C@H](O)[C@H](O)/C=C/C=C/C(=O)O[C@H]1C=C2COC(=O)[C@]2(O)[C@@]2(C)CCCC(C)(C)[C@H]12</smiles>

(84)<smiles>Cc1cc(O)cc(Oc2cc(C)cc3c2C[C@H](C(C)(C)O)O3)c1</smiles><smiles>C[C@H](O)[C@H](O)/C=C/C=C/C(=O)O[C@H]1C=C2COC(=O)[C@]2(O)[C@@]2(C)CCCC(C)(C)[C@H]12</smiles>

(85)<smiles>CC(=O)OC[C@]1(C)CCC[C@]2(C)[C@H]1[C@@H](OC(=O)c1ccc([N+](=O)[O-])cc1)C=C1C(=O)OC[C@@]12O</smiles>

Fig. 5 Chemical structure of compounds 74-88.

Chromatographic separation of the bioactive extract (anticancer) of the fungus Aspergillus europaeus WZXY-SX-4-1 derived from the marine sponge Xestospongia testudinaria has led to the isolation of various polyketide derivatives named eurobenzophenone B (103), euroxanthone A (104), 3-de- $O$ methylsulochrin (105), yicathin B (106), dermolutein (107), and methylemodin (108). These polyketides were tested for the inhibitory effects toward the NF- $\kappa$ B activation in SW480 human 
<smiles>C[C@]1(COC(=O)c2ccc([N+](=O)[O-])cc2)CCC[C@]2(C)[C@@H]1[C@H](O)C=C1C(=O)OC[C@@]12O</smiles>

(89)<smiles>C[C@]1(CO)CCC[C@H]2[C@H]1[C@H](OC(=O)c1ccc([N+](=O)[O-])cc1)C=C1C(=O)OC[C@@]12C</smiles>

(90)<smiles>COC(=O)[C@@]12CCCC(O)=C1C(=O)c1c(ccc(-c3ccc4c(c3O)C(=O)C3C(O)=C[C@H](C)[C@@H](O)[C@]3(C(=O)OC)O4)c1O)O2</smiles>

(91)<smiles>COC(=O)[C@]12Oc3ccc(-c4ccc5c(c4O)C(O)=C4C(O)=C[C@H](C)[C@@H](O)[C@]4(C(=O)OC)O5)c(O)c3C(=O)C1=C(O)CC[C@H]2O</smiles><smiles>COC(=O)[C@@]12Oc3ccc(-c4ccc5c(c4O)C(=O)C4[C@H](O)C[C@@H](C)[C@@H](O)[C@]4(C(=O)OC)O5)c(O)c3C(O)=C1C(O)=C[C@@H](CO)[C@H]2O</smiles>

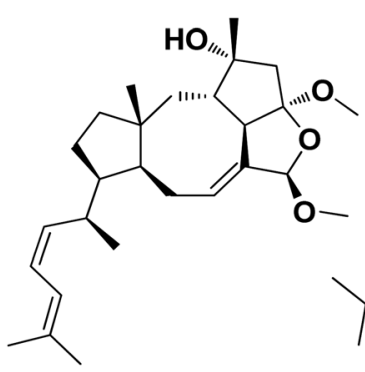

(94)<smiles>CC(C)=C/C=C\[C@H](C)[C@H]1CC[C@]2(C)C[C@H]3[C@H](C(=O)C[C@]3(C)O)/C(C=O)=C\C[C@H]12</smiles>

(95)

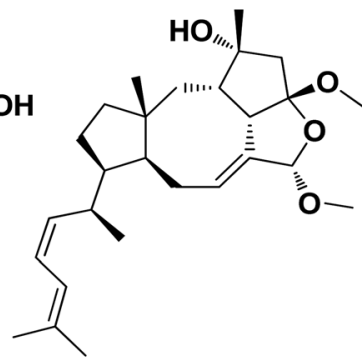

(96)<smiles>CC(C)=C/C=C\[C@H](C)[C@H]1CC[C@]2(C)C[C@H]3[C@H]4/C(=C\C[C@H]12)C(=O)O[C@]4(O)C[C@]3(C)O</smiles>

(97)<smiles>CC1=CC(=O)[C@H]2/C(C=O)=C\C[C@H]3[C@@H]([C@H](C)/C=C\[C@H](O)C(C)(C)O)CC[C@]3(C)C[C@H]12</smiles>

(98)<smiles>CO[C@H]1O[C@]2(OC)C[C@](C)(O)[C@@H]3C[C@@]4(C)CC[C@H]([C@H](C)/C=C\C=C(C)C)[C@H]4CC=C1[C@@H]32</smiles>

(99)

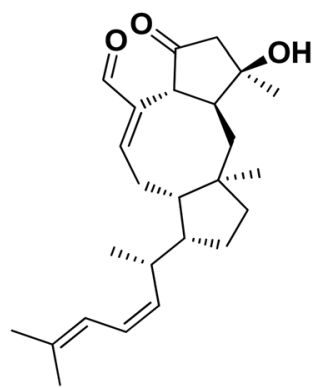

(100)<smiles>CC(C)=C/C=C/[C@H](C)[C@H]1CC[C@]2(C)C[C@H]3C(C)=CC(=O)[C@H]3/C(C=O)=C/C[C@@H]12</smiles>

(101)<smiles>CC(C)=C/C=C\[C@H](C)[C@H]1CC[C@]2(C)C[C@H]3C(C)=CC(=O)[C@H]3/C(OO)=C/C[C@H]12</smiles>

(102)<smiles>COC(=O)c1cc(O)cc(O)c1C(=O)c1c(O)cc(C)c(C(=O)OC[C@H](O)CO)c1O</smiles>

(103)<smiles>COC(=O)c1cc(C)c(C(=O)OC[C@H](O)CO)c2oc3cc(O)cc(O)c3c(=O)c12</smiles>

(104)

Fig. 6 Chemical structure of compounds 89-104.

colon carcinoma cell line, displaying remarkable repression of NF- $\kappa$ B expression in LPS-induced SW480 cells. ${ }^{43}$ Two naphtho- $c$ pyrones, rubrofusarine B (109) and fansecinone A (110), were purified from the marine-derived fungus Aspergillus foetidus KMM 4694. The effect of the substances on colony formation and viability of human drug-resistant prostate cancer cells 
<smiles>COC(=O)c1cc(O)cc(O)c1C(=O)c1c(O)c(Cl)c(C)c(Cl)c1O</smiles>

(105)<smiles>COC(=O)c1cc(OC)c2c(=O)c3c(O)cc(C)cc3oc2c1</smiles>

(106)<smiles>COc1cc(O)cc2c1C(=O)c1c(cc(C)c(C(=O)O)c1O)C2=O</smiles>

(107)<smiles>COc1cc(C)cc2c1C(=O)c1c(cc(O)c(Cl)c1O)C2=O</smiles>

(108)

(109)<smiles>COc1cc(OC)c2c(-c3c(OC)cc4cc(O)c5c(=O)cc(C)oc5c4c3OC)c3oc(C)cc(=O)c3c(O)c2c1</smiles><smiles>COc1cc(OC)c2c(O)c3c(c(-c4c(OC)cc5cc(O)c6c(=O)cc(C)oc6c5c4OC)c2c1)OC(C)(O)CC3=O</smiles>

(111)<smiles>CC(=O)OC[C@]1(C)[C@@H](OC(C)=O)CC[C@@]2(C)[C@@H]1C[C@H](OC(C)=O)[C@@]1(C)Oc3cc(-c4cccnc4)oc(=O)c3[C@@H]21</smiles>

(112)<smiles>C[C@]12CCC[C@@](C)(C(=O)O)[C@@H]1CC[C@]1(CO)OC(=O)C[C@H]12</smiles>

(113)<smiles>COC(=O)c1ccc(C(Cc2ccccc2)NC(C)=O)o1</smiles>

(114)<smiles>CCC(COC(=O)c1ccccc1C(=O)OCC(CC)CC(C)C)CC(C)C</smiles>

(115)<smiles>C=C(C(=C)C(=O)C(C)=C(O)C(=C)[C@@H](CC)OC)C(=O)C(C)=C(O)C(=C)C(=O)C(O)=CC</smiles>
116)

(117)<smiles>Cc1nnc(CNCCN2C(=O)c3cccc4cccc(c34)C2=O)s1</smiles><smiles>Cc1oc2c3c1[C@@H](C)C(C)C(=O)C=C3Oc1c3c(c(C)c(O)c1-2)[C@@H](C)[C@H](C)O3</smiles>

(119)<smiles>Cc1c(O)cc2c3c1[C@H](C)[C@H](C)O[C@H]3c1c(O)c(C)c3c(c1O2)O[C@H](C)[C@@H]3C</smiles>

(120)<smiles>CC1=C2C(=CO[C@@H](C)[C@@H]2C)C(=O)C(C(=O)O)=C1O</smiles>

(121)

Fig. 7 Chemical structure of compounds 105-121.

(22Rv1) was evaluated, leading to induction of ROS production in these cells in cytotoxic concentrations $(10.53 \%$ at $100 \mu \mathrm{M}$ and $12.53 \%$ at $10 \mu \mathrm{M}$, respectively). ${ }^{44} \mathrm{~A}$ naphthopyrone, namely fonsecinone $\mathrm{C}$ (111), was also isolated from the fungal strain Aspergillus niger 2HL-M-8 isolated from the mud sample, China (the intertidal zone, Huludao coastline). Fonsecinone C (111) 
demonstrated potent in vitro antiproliferative activity against cell lines A549, HL-60 and MGC-803. ${ }^{45}$

The fungal strain Aspergillus fumigatus YK-7, which was cultivated from an intertidal zone collected from sea mud sample, China, yielded a terpenoid named pyripyropene E (112). This terpenoidal metabolite showed potent antiproliferative activity against U937, the human leukemic monocyte lymphoma cancer cells, with an $\mathrm{IC}_{50}$ value of $4.2 \mu \mathrm{M} .{ }^{46}$ Chemical investigation of the fungal strain Aspergillus wentii SD-310, isolated from the South China Sea (a deep sea sediment sample), yielded a tetranorlabdane diterpenoid named asperolide $\mathrm{E}$ (113). Cytotoxicity of asperolides E (113) was tested against a number of various cell lines, exhibiting cytotoxic activity against cell lines of human carcinoma of the cervix (HeLa), human breast carcinoma (MCF-7) and NCI-H446, with IC $_{50}$ values of $10.0,16.0$ and $11.0 \mu \mathrm{M}$, respectively. ${ }^{47}$ A cytotoxic ester furan derivative (114) was isolated from the fungus Aspergillus niger obtained from the Northeast coast of Brazil (sediments). Cytotoxicity against HCT-116 (colon adenocarcinoma cell line) with $\mathrm{IC}_{50}$ was demonstrated by the compound at $2.9 \mu \mathrm{g} \mathrm{mL}{ }^{-1} .^{48}$

For investigating the River Nile habitat, isolation of Di-(2ethyl- hexyl) Phthalate (DEHP; 115) from fungus Aspergillus awamori had been performed. DEHP showed cytotoxic activity against MCF7, HEPG2, HCT 116 and HELA cell lines with IC $_{50}$ values of $6.525,26.73,66.607$ and 42.2958, respectively, concluding that the River Nile might be a tremendous resource for invention of bioactive metabolites. ${ }^{49}$ All anticancer marinederived Aspergillus metabolites are depicted in Fig. 1-7.

\section{Antibacterial activity}

Two anthraquinone dimers, namely 6,6'-oxybis(1,3,8-trihydroxy-2-((S)-1-methoxyhexyl)anthracene-9,10-dione) (116) and 6,6'-oxybis(1,3,8-trihydroxy-2-((S)-1-hydroxyhexyl) anthracene9,10-dione) (117) were isolated from the marine-derived fungus Aspergillus versicolor. Both compounds displayed selective antibacterial activity against Gram-positive Staphylococcus aureus (30 $\mu \mathrm{g}$ per well). ${ }^{50}$ Sponge-associated Aspergillus strain LS116 yielded a C23 steroid with bicyclo[4.4.1]A/B ring, namely aspergillsteroid A (118). This compound displayed significant anti-bacterial activity against $V$. harvey $i$ with a MIC value of 16 $\mu \mathrm{g} \mathrm{mL}^{-1}$, demonstrating that aspergillsteroid A (118) could be considered one of promising agents for the aquatic disease control in the future. ${ }^{51}$

Chitosan polysaccharide was produced from unconventional sources, the marine-derived fungus Aspergillus griseoaurantiacus KX010988 by solid state fermentation of potato shells. Chitosan showed good antibacterial activity against $S$. aureus, Bacillus subtilis, and Lactobacillus cereus with inhibition zone diameter $=21 \pm 0.81,19 \pm 0.80$ and $20 \pm 0.71$, respectively by $40 \mu \mathrm{g}$ per well. ${ }^{22}$

Three analogues of citrinin, namely penicitrinone $\mathrm{F}$ (119), penicitrinol A (120) and citrinin (121), were isolated from the coculture extracts of Penicillium citrinum EN-535 and Aspergillus sydowii EN-5344, two marine algal-derived endophytic fungal strains. The antimicrobial activity of the three compounds against $V$. parahaemolyticus, M. luteus, Ed. ictaluri, $V$. alginolyticus and E. coli was evaluated, showing strong inhibition with $\mathrm{IC}_{50}$ values varying from 4 to $64 \mu \mathrm{g} \mathrm{mL}{ }^{-1} \cdot{ }^{53}$ A meroterpenoid, terretonin G (122) was isolated from the Aspergillus terreus EN-539, marine algal-derived endophytic fungus. This meroterpenoidal metabolite showed inhibitory activity against S. aureus and Micrococcus luteus, with MIC values of 8 and $32 \mu \mathrm{g}$ $\mathrm{mL}^{-1}$, respectively. ${ }^{54}$ Two aminobenzoic peptides, secoclavatustide B (123) and clavatustide B (124) and a clavatoic acid derivative, 5-acetyl-2,4-dihydroxy-3-methylbenzoic acid (125), were characterized from the ascidian-derived endophytic fungus Aspergillus clavatus AS-107 (EtOAc extracts). The isolates were evaluated for various antimicrobial activities against aquatic and human pathogenic bacteria. Seco-clavatustide B (123) and clavatustide B (124) showed potent activity against Pseudomonas aeruginosa and Aeromonas hydrophila (aquatic pathogens) with MIC values of 8.8 and $8.2 \mu \mathrm{M}$, respectively. The clavatoic acid derivative (125) exhibited definite bacterial inhibitory activity against $M$. luteus with an MIC value of 38.1 $\mu \mathrm{M} .^{55}$ An indoloditerpene, $(3 R, 9 S, 12 R, 13 S, 17 S, 18 S)$-2-carbonyl3-hydroxylemeniveol (126) was isolated from a marine-derived fungus Aspergillus versicolor ZZ761. This indoloditerpene showed antimicrobial activities against Escherichia coli with a MIC value of $20.6 \mu \mathrm{M}^{17}$

Five aromatic bisabolene-type sesquiterpenoid, named $(7 R, 11 S)$ - 12 methyl hydroxylated sydowic acid (127), aspergoterpenin $\mathrm{C}(\mathbf{1 2 8}),(7 S, 11 S)-(+)-12-h y d r o x y s y d o n i c ~ a c i d ~(129), ~(S)-$ (+)-11-dehydrosydonic acid (130), and engyodontiumone I (131) were isolated and characterized from the Aspergillus versicolor SD-330 fungus originated from deep-sea sediments. These compounds were tested for antimicrobial activities against aquatic and human pathogenic bacteria. Selective inhibitory activity against E. coli, Aeromonas hydrophilia, Vibrio harveyi and Edwardsiella tarda zoonotic pathogenic bacteria was observed, in particular $(7 R, 11 S)-12$ methyl hydroxylated sydowic acid (127), aspergoterpenin C (128) and engyodontiumone I (131), with MIC values ranging between 1.0 and $8.0 \mu \mathrm{g} \mathrm{mL}{ }^{-1} .^{56} \mathrm{~A}$ promising polyextremophilic marine fungus strain $8 \mathrm{Na}$, known as Aspergillus protuberus MUT 3638, with the potential to produce antimicrobial metabolites, was isolated during the bioassay-guided method. Bisvertinolone (132), a sorbicillonoid, which was found to exhibit a major antibacterial activity against $S$. aureus, was identified as the active principle with a MIC $30 \mu \mathrm{g}$ $\mathrm{mL}^{-1} .57$

Anthraquinone questin (133) from marine Aspergillus flavipes HN4-13 against $V$. harveyi (aquatic pathogenic) was investigated, in the basis of searching for the mechanistic pathway of its antibacterial activity. It exhibited favorable antibacterial and bactericidal activity against $V$. harveyi via disrupting the cell membrane and wall, which caused the destruction of integrity and permeability of cell membrane and wall, resulting in the intracellular biological components leakage and cell morphology change with MIC value of $31.25 \mu \mathrm{g} \mathrm{mL}{ }^{-1} .^{58}$ Antibacterial activities against various Gram-positive bacteria were seen in the Aspergillus flavipes DL-11 strain extract. Ten biphenyl ethers, namely 4'-chloroasterric acid (134), chloroasterrate (135), penicillither (136), iizukine A (137), asterric acid (138), monomethylosoic acid (139), butyl 2,4-dichloroasterrate (140), 
2,4-dichloroasterric acid (141), methyl dichloroasterrate (142) and geodin hydrate (143), two benzophenones, named monochlorsulochrin (144) and dihydrogeodin (145) together with two xanthones, methyl(2-chloro-l,6-dihydroxy-3-meth-ylxanthone)8-carboxylate (146) and methyl(4-chloro-1,6-dihydroxy-3methylxanthone)-8-carboxylate (147), were isolated by bioassay-guided separation. All metabolites demonstrated moderate to strong antibacterial activity with MIC values ranging from 3.13 to $50 \mu \mathrm{g} \mathrm{mL}^{-1}$ on six Gram-positive bacteria. In particular, the MICs of certain isolates are at the level of positive control. ${ }^{59}$

Three pyrazin-2(1H)-one derivatives, ochramide B (148), ochralate A (149), as well as aluminiumneoaspergillin (150), were isolated from of the marine coral-derived halotolerant Aspergillus ochraceus LCJ11-102 (fermentation broth in a nutrient-limited medium containing $10 \%$ sodium iodide). The isolated derivatives exerted antimicrobial effects with MIC values of 40.0, 18.9 and $20.1 \mu \mathrm{M}$, respectively, against Enterobacter aerogenes. ${ }^{60}$ Five polyketides were isolated from the marine-derived fungus Aspergillus sp. ZF-79, named asperochrins A (151), D (152) and F (153), (3R,4R)-4,7-dihydroxymellein (154), and asteltoxin (155). All the isolates were tested for quorum sensing inhibitory activity (QSI), exhibiting QSI activity against Chromobacterium violaceum CV026 with MIC values of 50, 100, 50, 50, and $6.25 \mu \mathrm{M}$, respectively. ${ }^{61}$ A diphenyl derivative, dichloroasterric acid (141) was isolated from the fungus Aspergillus sp. derived from the soft coral Sinularia sp., the South China Sea. Furthermore, five pathogenic bacterial strains, S. aureus (ATCC 25923), Escherichia coli (ATCC 35401), Pseudomonas aeruginosa (ATCC 9027), Vibrio parahaemolyticus (ATCC 19019) and Vibrio anguillarum (ATCC 17802), were used to investigate the antibacterial activity of this diphenyl derivative (positive control was ciprofloxacin), displaying selective inhibition against $S$. aureus with the MIC value of $12.5 \mu \mathrm{M}^{21}$

In the course of investigation on potent nontoxic antibacterial agents from coral-derived fungi in the South China Sea, two biphenyl derivatives with cytotoxic and antimicrobial activities, sulochrin (156) and (-)-bis-dechlorogeodin (157) were isolated from a soft coral-derived fungus Aspergillus sp. These biphenyls were tested on the basis of chemical ecology for their antimicrobial activities against different pathogenic microorganisms, including the bacteria $E$. coli, $P$. aeruginosa and $S$. aureus, exhibiting strong antibacterial activity against $P$. aeruginosa with MICs of 7.53 and $3.78 \mu \mathrm{M}$ (ciprofloxacin, $\mathrm{MIC}=1.88 \mu \mathrm{M}$ ), respectively. ${ }^{62}$

Investigation of EtOAc extract of a gorgonian-derived fungus, Aspergillus versicolor led to the isolation of two secoanthraquinones, namely (+)-geodin (32) and chlorotrypacidin (34). The antibacterial effects of both compounds were tested, showing antibacterial activity against Vibrio anguillarum, Staphylococcus albus and $S$. aureus, with a standardized MIC value of $25.0 \mu \mathrm{M} .{ }^{23}$ Prenylated $p$-terphenyls, prenylterphenyllins $\mathrm{H}-\mathrm{J}$ (37-39), were isolated from the Aspergillus candidus LDJ-5 (a marine-endophytic fungus). The three compounds were active as antimicrobials against Proteus species, P. aeruginosa and $B$. subtilis with $\mathrm{IC}_{50}$ values varying from 22 to $90 \mu \mathrm{g} \mathrm{mL}{ }^{-1} \cdot{ }^{24}$ The fungal strain Aspergillus alabamensis EN-547 was derived from the Ceramium japonicum, one of marine red alga species (fresh inner tissue), leading to the isolation of 3 diketomorpholine derivatives, namely 4-epi-seco-shornephine A methyl ester (158), 4-epi-seco-shornephine A carboxylic acid (159) and shornephine A (160) together with a highly conjugated ergostane-type steroid, 28-acetoxy-12b,15a,25-trihydroxyergosta-4,6,8(14),22tetraen-3-one (161). These metabolites were assayed for antimicrobial activities against E. coli and Micrococcus luteus (two human pathogens) and five marine bacteria (Vibrio alginolyticus, Edwardsiella ictaluri, V. anguillarum, V. vulnificus and V. parahaemolyticus), showing inhibitions against aquatic bacteria (Ed. ictaluri and $V$. alginolyticus) and human pathogens (E. coli and $M$. luteus), with MIC values ranging between 16 and $64 \mu \mathrm{g}$ $\mathrm{mL}^{-1} .^{63}$

A hydroxypyrrolidine alkaloid, preussin (81), a bis-indolyl benzenoid, petromurin $\mathrm{C}$ (42) and chrysophanic acid (53) anthraquinone, were isolated from the Aspergillus candidus KUFA 0062, one of marine sponge-associated fungi. For their antibacterial activity against Gram-negative and Gram-positive reference and other environmental multidrug resistant strains, all metabolites were evaluated. Preussin (81) exhibited an inhibitory effect against E. faecalis ATCC29212 and S. aureus ATCC 29213 as well as both vancomycin-resistant enterococci (VRE) and methicillin-resistant $S$. aureus (MRSA) strains. Both preussin (81) and chrysophanic acid (53) caused significant reduction of biofilm production in E. coli ATCC 25922. Moreover, petromurin $\mathrm{C}(\mathbf{4 2})$ and preussin revealed a synergistic effect with oxacillin towards MRSA $S$. aureus 66/1 while preussin (81) exhibited a strong synergistic inhibition with the colistin antibiotic against E. coli $1410 / 1 .^{30}$ From the fungus Aspergillus sp. ZA-01, seven prenylxanthone derivatives, aspergixanthones A (43) and I-K (162-164), and other analogues, 15-acetyl tajixanthone hydrate (165), tajixanthone hydrate (166), and 16chlorotajixanthone (167) were obtained. All the isolates were tested for their anti-Vibrio activities. Aspergixanthone I (162) displayed the strongest anti-Vibrio activity, in particular against $V$. parahaemolyticus $(\mathrm{MIC}=1.56 \mu \mathrm{M}), V$. anguillarum $(\mathrm{MIC}=$ $1.56 \mu \mathrm{M}$ ), and $V$. alginolyticus (MIC $=3.12 \mu \mathrm{M}$ ), whilst other isolates showed inhibition with $\mathrm{IC}_{50}$, ranging between 1.56 and $25.0 \mu \mathrm{M} .^{64}$

A tetrahydroxanthone dimer, 5-epi-asperdichrome (168), was isolated from the Aspergillus versicolor HDN1009, a mangrovederived fungus. This compound is a type of tetrahydroxanthone dimers. This dimer showed promising antibacterial activities against $B$. subtilis, $P$. aeruginosa and $V$. parahaemolyticus with MIC values ranging between $100 \mu \mathrm{M}$ and 200 $\mu \mathrm{M} .^{31}$ A sterol; ergosta-5,7,22-triene-3b-ol (169), a norsterol; volemolide (170), an indole alkaloid; oxaline (171), an indolyl diketopiperazine alkaloid; fumitremorgin B (172), a tricyclic triterpene; helvolic acid (173), and (E)-4-oxonon-2-enoic acid (174), were purified from the fermentation broth of a bivalve mollusk, Sanguinolaria chinensis associated with Aspergillus sp. SCS-KFD66, China. The growth inhibitory activity of these metabolites against four pathogenic bacterial strains ( $S$. aureus ATCC 6538, E. coli ATCC 25922, Bacillus subtilis ATCC 6633 and Listeria monocytogenes ATCC 1911), were assessed. Inhibitory effect with MIC values ranging from 2 to $128 \mu \mathrm{g} \mathrm{mL}^{-1}$ was 
<smiles>C=C1C[C@@]2(C)C(=O)[C@H](C)OC(=O)[C@@H]2[C@]2(C)C(=O)C(=O)[C@@]1(C)[C@@]1(C)CCC(=O)C(C)(C)C1=C(O)C2=O</smiles>

(122)<smiles>CC(Cc1ccccc1)[C@H](OC(=O)c1ccccc1NC(=O)c1ccccc1NC(=O)CN(C)C(=O)C1CCCCC1)C(N)=O</smiles><smiles>CC(=O)c1cc(C(=O)O)c(O)c(C)c1O</smiles>

(125)<smiles>C=C1[C@H](C[C@]2(O)C(=O)Nc3ccccc32)CC[C@@H]2[C@](C)(CCC=C(C)C)[C@H](O)CC[C@@]12C</smiles>

(126)<smiles>COC(=O)c1ccc([C@@](C)(O)CCC[C@H](C)CO)c(O)c1</smiles>

(129)

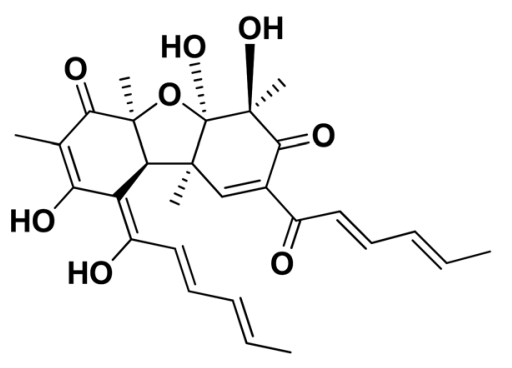

(132)<smiles>COC(=O)c1cc(O)cc(OC)c1Oc1c(Cl)c(C)cc(O)c1C(=O)OC</smiles>

(136)<smiles>COC(=O)c1c(Oc2c(OC)cc(O)cc2C(=O)O)cc(C)c(Cl)c1O</smiles>

(137)<smiles>C[C@@]1(c2c(O)cc(C(=O)O)cc2O)CCC[C@](C)(CO)O1</smiles>

(127)<smiles>C=C(C)CCC[C@](C)(O)c1ccc(C(=O)O)cc1O</smiles>

(130)<smiles>COC(=O)c1ccc([C@](C)(O)CCCC(C)(C)O)c(O)c1</smiles>

(128)<smiles>C/C(=C\CCC(C)(C)O)c1ccc(C(=O)O)cc1O</smiles>

(131)<smiles>COc1cc(O)cc2c1C(=O)c1c(O)cc(C)cc1C2=O</smiles><smiles>COC(=O)c1cc(O)cc(OC)c1Oc1cc(C)c(Cl)c(O)c1C(=O)OC</smiles>

(135)

Fig. 8 Chemical structure of compounds 122-139.

observed in all compounds. ${ }^{65}$ Two biphenyl derivatives, diorcinol J (175) and 4-methoxycarbonyldiorcinol (176), were isolated from the Aspergillus versicolor OUCMDZ-2738. These compounds showed selective antibacterial effects against $P$. aeruginosa with a MIC of 17.4 and $13.9 \mu \mathrm{M}$, respectively. ${ }^{66}$
Three helvolic acid derivatives, namely 16-O-propionyl-16-Odeacetylhelvolic acid (177), 6-O-propionyl-6- $O$-deacetylhelvolic acid (178) and helvolic acid (173), were isolated from the marine-derived fungus Aspergillus fumigatus CUGBMF17018. The antibacterial activities against both MRSA and S. aureus 
<smiles>CCCOC(=O)c1c(Oc2c(OC)cc(O)cc2C(=O)OC)cc(Cl)c(Cl)c1O</smiles>

(140)<smiles>COC(=O)c1cc(O)cc(OC)c1Oc1cc(Cl)c(Cl)c(O)c1C(=O)O</smiles>

(141)<smiles>COC(=O)c1cc(O)cc(OC)c1Oc1c(Cl)c(C)c(Cl)c(O)c1C(=O)OC</smiles>

(142)<smiles>COC(=O)c1cc(O)cc(OC)c1Oc1c(Cl)c(C)c(Cl)c(O)c1C(=O)O</smiles><smiles>C=C(c1c(OC)cc(O)cc1C(=O)OC)c1c(O)ccc(Cl)c1OC</smiles>

(144)<smiles>COC(=O)c1cc(O)cc(OC)c1C(=O)c1c(O)c(Cl)c(C)c(Cl)c1O</smiles>

(145)<smiles>COC(=O)c1cc(O)cc2c1C(=O)C1C(O)=C(Cl)C(C)=C(C)C1O2</smiles>

(146)<smiles>COC(=O)c1cc(O)cc2c1C(=O)C1C(O)=CC(C)=C(Cl)C1O2</smiles>

(147)<smiles>CO[C@H](c1ncc(CC(C)C)[nH]c1=O)C(C)C</smiles>

(148)<smiles>COC(c1ncc(CC(C)C)n(O[Al](On2c(CC(C)C)cnc(C(OC)C(C)C)c2=O)On2c(CC(C)C)cnc(C(OC)C(C)C)c2=O)c1=O)C(C)C</smiles><smiles>CC(C)Cc1ncc(CC(C)C)n(O[Al](On2c(CC(C)C)cnc(CC(C)C)c2=O)On2c(CC(C)C)cnc(CC(C)C)c2=O)c1=O</smiles><smiles>C[C@H](O)/C=C1\C(=O)O[C@@H]([C@@H](C)O)[C@@H]1O</smiles><smiles>CC1OC(=O)/C(=C\[C@H](O)[C@H](C)O)[C@H]1O</smiles>

(152)<smiles>COC(=O)c1cc(O)cc(OC)c1C(=O)c1c(O)cc(C)cc1O</smiles>

(156)<smiles>C[C@@H]1OC(=O)c2c(ccc(O)c2O)[C@H]1O</smiles>

(153)<smiles>COC(=O)C1=CC(=O)C=C(OC)C12Oc1cc(C)cc(O)c1C2=O</smiles>

(157)<smiles>C[C@@H]1OC(=O)c2c(ccc(O)c2O)[C@H]1O</smiles>

(154)<smiles>CC[C@H]1OC2O[C@@H](/C=C/C=C/C=C/c3oc(=O)cc(OC)c3C)[C@@H](O)[C@@]2(C)[C@@]1(C)O</smiles>

(155)<smiles>C=CC(C)(C)C1(CC(NC(=O)C(O)Cc2ccccc2)C(=O)OC)C(=O)Nc2c(O)cccc2C1(CC(NC(=O)C(O)Cc1ccccc1)C(=O)OC)C(=O)OC</smiles>

(158)

Fig. 9 Chemical structure of compounds 140-159.

were shown by these compounds, with MIC values of between 0.78 and $12.5 \mu \mathrm{g} \mathrm{mL}{ }^{-1} \cdot{ }^{67}$ Nine prenylated diphenyl ether compounds, diorcinols C-E (179-181), and J (175), $(R)$-diorcinol B (182), $(S)$-diorcinol B (183), 9-acetyldiorcinol B (184), and a dihydrobenzofuran derivative (87), were isolated from one of the marine algal-derived endophytic fungi, Aspergillus tennesseensis (87). These isolates were examined for antimicrobial effects, exhibiting antimicrobial activities against some plant 
and human pathogenic microbes (MIC values varying between 2-64 $\left.\mu \mathrm{g} \mathrm{mL} \mathrm{m}^{-1}\right) .^{39}$

An indole alkaloid, fumigatoside $\mathrm{F}$ (185) and an indole alkaloid, fumiquinazoline $\mathrm{G}$ (186), were purified from the fungus Aspergillus fumigatus SCSIO 41012 (deep-sea derived). Moreover, all compounds were assayed for antibacterial inhibitory activities. Fumiquinazoline G (186) exhibited the most significant activities against $S$. aureus (29 213 and 16 339) with MIC values of 0.78 and $1.56 \mu \mathrm{g} \mathrm{mL}{ }^{-1}$, respectively, and an important inhibitory activity against $A$. baumanii ATCC 19606 was seen with fumigatoside $\mathrm{F}$ (185), with a $6.25 \mu \mathrm{g} \mathrm{mL}{ }^{-1}$ MIC value. ${ }^{68}$ Chemical investigation of the Aspergillus sydowii SW9 (sea water-derived fungus) led to the purification of two quinazolinone alkaloids, 2-(4-hydroxybenzyl)-4-(3-acetyl)quinazolin-one (187) and 2-(4hydroxybenzoyl)-4(3H)-quinazolinone (188), and one aromatic bisabolene-type sesquiterpenoid (189). These metabolites displayed selective inhibitory effects on the human pathogenic bacteria S. aureus, E. coli, S. epidermidis and Streptococcus pneumoniae, with MIC values varying between 2.0 and $16 \mu \mathrm{g} \mathrm{mL}{ }^{-1}{ }^{69}$

An anthraquinone, 2-(dimethoxymethyl)-1-hydroxyanthracene9,10-dione (190), was isolated from the deep sea sediment fungus Aspergillus versicolor. It showed strong inhibitory activities against MRSA CGMCC 1.12409 and MRSA ATCC 43300 (MIC values of 7.8 and $3.9 \mu \mathrm{g} \mathrm{mL} \mathrm{m}^{-1}$, respectively). Molecular docking tests were added to this metabolite to suppress the enzymes AmpC $\beta$-lactamase and topoisomerase IV, signaling its utility as an antimicrobial agent. ${ }^{70}$ Three diphenyl ethers, diorcinols K (191), D (192) and I (193), were isolated from the marine fungus Aspergillus sp. CUGB-F046, the Bohai Sea (a sediment sample), China. Such metabolites displayed considerable antibacterial activities towards methicillin-resistant $S$. aureus with MIC values of 3.125, 6.25 and $6.25 \mu \mathrm{g} \mathrm{mL}{ }^{-1}$, respectively. ${ }^{71}$ Circumdatin F (194), a benzodiazepine alkaloid was purified from the deep sea fungus Aspergillus westerdijkiae SCSIO 05233 that was isolated from a sediment sample collected at the depth of $4593 \mathrm{~m}$ from the South China Sea. This alkaloid was examined for antifouling activity, displaying remarkable antifouling activity with $\mathrm{EC}_{50}$ value of $8.81 \mu \mathrm{g} \mathrm{mL}{ }^{-1} .^{72}$ A study of the fungal strain A. wentii SD-310 described the isolation of five 20-nor-isopimarane diterpenoids, namely aspewentins A (195), D (196), F-H (197-199). All the isolates were evaluated for their antimicrobial effects against seven aquatic pathogens and two human pathogenic bacteria, showing inhibitory activity against various aquatic pathogens Micrococcus luteus, Edwardsiella tarda, Pseudomonas aeruginosa, Vibrio parahaemolyticus and $V$. harveyi, each with MIC values of $4.0 \mu \mathrm{g} \mathrm{mL}{ }^{-1} .^{73}$

An antibacterial anthraquinone, 2-(dimethoxymethyl)-1hydroxyanthracene-9,10-dione (200), was separated from a marine deep sea-derived A. versicolor, recovered from sediments collected at a depth of $2869 \mathrm{~m}$ in the West Pacific Ocean. The anthraquinone displayed strong antibacterial activities against MRSA CGMCC 1.12409 and MRSA ATCC 43300 (MIC values of 7.8 and $3.9 \mu \mathrm{g} \mathrm{mL}^{-1}$, respectively). Molecular docking studies of the anthraquinone with AmpC $\beta$-lactamase and topoisomerase IV showed least binding energy. ${ }^{74}$

A highly conjugated steroid, (22E)-ergosta-4,6,8(14),22,24(28)pentaen-3-one (201), together with two steroid derivatives, $(4 S, 17 R)$-4-hydroxy-17-methylincisterol (202) and chaxine C (203), in addition to five butyrolactone derivatives, 2-O-methylbutyrolactone I (204) and II (205), demethoxycarbonylbutyrolactone II (206), butyrolactones I (207) and III (208), were isolated from the marine-derived fungus Aspergillus sp. XS-20090B15 recovered from the fresh gorgonian Muricella abnormalis, The South China Sea (the Xisha Islands coral reef). The 2-O-methylbutyrolactone I (204) and II (205) butyrolactone derivatives demonstrated significant antibacterial activities against $S$. Aureus with a MIC value of $1.56 \mu \mathrm{M}$. On the other hand, the steroid derivatives, (22E)-Ergosta-4,6,8(14),22,24(28)-pentaen-3-one (201), $(4 S, 17 R)$-4hydroxy-17-methylincisterol (202), chaxine C (203) in addition to the butyrolactone derivatives, 2-O-methylbutyrolactone II (205), demethoxycarbonylbutyrolactone II (206), butyrolactone I (207) and III (208) displayed potent antifouling activities against Balanus amphitrite with $\mathrm{EC}_{50}$ values ranging between 0.63 and 18.4 $\mu \mathrm{g} \mathrm{mL}^{-1} \cdot{ }^{75}$ Di-(2-ethyl-hexyl) phthalate (DEHP; 115) compound from fungus Aspergillus awamori also exhibited activity against Gram positive bacteria Sarcina lutea with inhibition diameter zone of $23 \mathrm{~mm} \cdot{ }^{49}$ All antibacterial marine-derived Aspergillus metabolites are depicted in Fig. 2, 3, 5 and 7-12.

\section{Anti-inflammatory}

An ochratoxin derivative named ochratoxin $A_{1}(209)$ was obtained from the Aspergillus ochraceopetaliformis, a spongederived fungus. Ochratoxin $A_{1}$ (209) exhibited antiinflammatory activity against IL-6 of the LPS-induced THP-1 cells and against TNF- $\alpha$ expression with inhibitory rates of $67.7 \%$ and 74.4 at concentration of $10 \mu \mathrm{M}$, respectively. ${ }^{76}$ Two Diels-Alder additive steroids, ergosterdiacids A (210) and B (211), were obtained from the Aspergillus sp. DM29 (mangrovederived fungus strain). These steroids displayed strong in vitro anti-inflammatory effects via the NO production suppression at 4.5 and $3.6 \mu \mathrm{M}$, respectively. ${ }^{77}$ Aromatic butenolides, asperimides C (212) and D (213) were isolated from of a tropical endophytic fungus Aspergillus terreus SC1550 (solid cultures). The inhibitory effects of these butenolides on nitric oxide (NO) production were studied in lipopolysaccharide (LPS)-mediated RAW 264.7 cells, exhibiting a powerful anti-inflammatory effect with $\mathrm{IC}_{50}$ values of $0.78 \pm 0.06$ and $1.26 \pm 0.11 \mu \mathrm{M} .^{78}$ Deoxy-7,14-didehydrosydonol (214), a sesquiterpene derivative was obtained from Aspergillus versicolor SYSU-SKS025, a mangrove endophytic fungus. This metabolite exerted inhibition of NO production in RAW 264.7 macrophages with $\mathrm{IC}_{50}$ value of $12.5 \mu \mathrm{M}^{79}$

A fungal metabolite, 6,8,1'-tri-O-methylaverantin, an anthraquinone (215) was isolated from the Aspergillus sp. SF6796, a marine-derived fungal strain. This anthraquinone induces heme oxygenase (HO)-1 protein up-regulation, which is present in microglial BV2 cells. HO-1 protein induction was mediated by the activation of Nrf2 (nuclear transcription factor erythroid-2 associated factor 2), and additionally was regulated by phosphatidylinositol 3-kinase/protein kinase B and the p38 mitogen-activated protein kinase signaling pathways. In addition, 6,8,1'-tri-O-methylaverantin (215) caused overproduction suppression of prostaglandin E2 and NO (pro-inflammatory mediators), such as, with $\mathrm{IC}_{50}$ values of $2.59 \pm 0.39$ and 5.62 
<smiles>C=CC(C)(C)[C@]12Nc3c(O)cccc3[C@@]1(O)C[C@H]1C(=O)O[C@@H](Cc3ccccc3)C(=O)N12</smiles>

(160)<smiles>CC(=O)OC[C@H](/C=C/[C@H](C)[C@H]1C[C@H](O)C2=C3C=CC4=CC(=O)CC[C@]4(C)[C@H]3C[C@H](O)[C@]21C)C(C)(C)O</smiles><smiles>C=C(C)[C@@H]1COc2c(C)cc3oc4c(C[C@H](OC(C)=O)C(C)(C)O)ccc(O)c4c(=O)c3c2[C@H]1O</smiles><smiles>C=C(C)[C@H](O)[C@@H](OC)c1ccc(O)c2c(=O)c3c4c(c(C)cc3oc12)OC[C@H](C(=C)C)[C@H]4OC(C)=O</smiles>

(163)<smiles>C=C(C)[C@H](O)[C@@H](OC)c1ccc(O)c2c(=O)c3c4c(c(C)cc3oc12)OC[C@H](C(=C)C)[C@H]4O</smiles>

(164)<smiles>C=C(C)[C@@H]1COc2c(C)cc3oc4c(C[C@H](OC(C)=O)C(C)(C)O)ccc(O)c4c(=O)c3c2[C@H]1O</smiles>

(165)<smiles>C=C(C)[C@H]1COc2c(C)cc3oc4c(C[C@H](O)C(C)(C)O)ccc(O)c4c(=O)c3c2[C@H]1O</smiles>

(166)<smiles>C=C(C)[C@H]1COc2c(C)cc3oc4c(C[C@H](O)C(C)(C)Cl)ccc(O)c4c(=O)c3c2[C@H]1O</smiles><smiles>COC(=O)[C@@]12Oc3cccc(Oc4cccc5c4C(O)=C4C(=O)C[C@@H](C)[C@H](O)[C@]4(C(=O)OC)O5)c3OC1=C1C(=O)C[C@@H](C)[C@H](O)[C@]12C(=O)O</smiles>

(168)<smiles>CC(C)[C@H](C)/C=C/[C@H](C)[C@H]1CC[C@H]2C3=CC=C4C[C@@H](O)CC[C@]4(C)[C@H]3CC[C@]21C</smiles>

(169)<smiles>CO[C@]12CC[C@@]3(C)[C@@H](CC[C@@H]3[C@H](C)/C=C/[C@H](C)C(C)C)C1=CC(=O)O2</smiles>

(170)<smiles>C=CC(C)(C)[C@]1(c2ccccc2)C=C(OC)C(=O)N2/C(=C/c3cnc[nH]3)C(=O)N[C@]21NOC</smiles>

(171)<smiles>COc1ccc2c3c(n(CC=C(C)C)c2c1)[C@@H](O)[C@]1(O)C(=O)N2CCC[C@H]2C(=O)N1[C@H]3C=C(C)C</smiles>

(172)

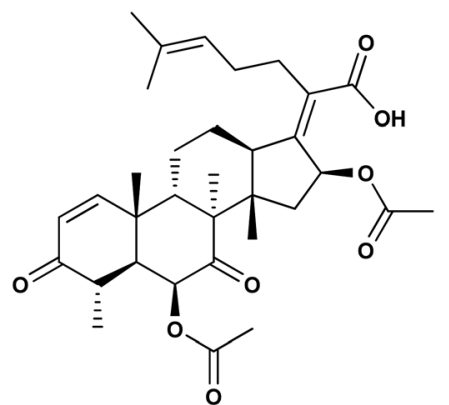

(173)

Fig. 10 Chemical structure of compounds 160-173.

$\pm 0.18 \mathrm{mM}$, respectively, inducible cyclooxygenase- 2 and nitric oxide synthase, in lipopolysaccharide (LPS)-stimulated BV2 microglial cells. The anti-neuroinflammatory effects were mediated via the down-regulation of the nuclear factor kappa B (NFKB) mechanistic pathway, suppressing translocation into the nucleus of p65/p50 heterodimer, the degradation and phosphorylation of inhibitor kappa B-a and p65 subunit DNA- binding activity. A selective HO-1 inhibitor has partly repressed the anti-neuroinflammatory activity of $6,8,1^{\prime}$-tri-Omethylaverantin (215), indicating that its antineuroinflammatory effect is relatively mediated by induction of HO-1. HO-1 protein expression in primary microglial cells is also up-regulated by 6,8,1'-tri- $O$-methylaverantin (215), which 
may be associated with anti-neuroinflammatory effects found in LPS-stimulated primary microglial cells. ${ }^{80}$

Butyrolactone-I (ZB5-1; 216) from the Aspergillus terreus (coral-derived fungus) was explored for its antineuroinflammatory activity on lipopolysaccharide (LPS)induced BV-2 microglia cells. ZB5-1 (216) in tested concentrations significantly reduced the production of $\mathrm{NO}$, and interleukin-1 beta (IL-1 $\beta$ ). The dose-dependent expression of inducible nitric oxide synthase (iNOS) and cyclooxygenase-2 (COX-2) was also down-regulated by ZB5-1 (216). Moreover, the effect of ZB5-1 (216) on the signaling pathway of nuclear factor $-\kappa B(N F-\kappa B)$ that was studied through evaluation of the expression of phosphorylation of inhibitor of NF- $\kappa \mathrm{B}$ and (I $\kappa \mathrm{B}$ ) $\mathrm{NF}-\kappa \mathrm{B}$ p65, and the nuclear translocation of $\mathrm{NF}-\kappa \mathrm{B}$ p65, respectively. Moreover, molecular docking study proposed that ZB5-1 (216) bound at the $\mathrm{NF}-\kappa \mathrm{B}$ active sites, preventing its translocation to the nucleus. ${ }^{81}$ Three derivatives of ochratoxin, called ochratoxin A1 (209), ochratoxin B (68) and ochratoxin B methyl ester (217) were isolated from the Aspergillus ochraceopetaliformis, a sponge-derived fungus. These ochratoxins exhibited anti-inflammatory activity against expression of both TNF- $\alpha$ and IL- 6 of the LPS-induced THP-1 cells with inhibitory rates of $67.7 \%, 74.4$ (ochratoxin $\mathrm{A} 1 ; 209$ ), $72.8 \%$, 91.6 (ochratoxin $\mathrm{B} ; 68$ ) and $72.9 \%, 89.7 \%$ (ochratoxin B methyl ester; 217) at a uniform concentration of $10 \mu \mathrm{M}$, respectively. ${ }^{82}$

Aspersecosteroids A (218) and B (219), 11(9 $\rightarrow$ 10)-abeo-5,10secosteroids together with an ergosteroid named asperflosterol (220), were purified from the sponge-derived fungus Aspergillus flocculosus 16D-1. These steroids displayed inhibitory activities on key pro-inflammatory cytokine output in THP-1 cells. Wagner-Meerwein rearrangement, oxidative cleavage (biogenetic pathway) and sequential acetalization as key steps is suggested for the two secosteroids. ${ }^{83}$ A prenylated tryptophan derivative, luteoride $\mathrm{E}$ (221), a butenolide derivative, versicolactone $\mathrm{G}$ (222), a linear aliphatic alcohol, $(3 E, 7 E)$-4,8-dimethyl-undecane3,7-diene-1,11-diol (223), together with an alkaloid, methyl 3,4,5-trimethoxy-2-(2-(nicotinamido)benzamido)benzoate (224), a steroid, $14 \alpha$-hydroxyergosta-4,7,22-triene-3,6-dione (225), territrem A (226), and lovastatin (227), were isolated from Aspergillus terreus, a coral-associated fungus. These isolates were evaluated for their anti-inflammatory activity against NO production, exhibiting potent inhibition with $\mathrm{IC}_{50}$ values ranging between 5.48 and $29.34 \mu \mathrm{M}^{84}$

Three meroterpenoids, aspermeroterpenes A-C (228-230), were isolated from Aspergillus terreus GZU- 31-1, a marine-derived fungus. These compounds displayed significant inhibitory effects against lipopolysaccharide (LPS)-induced nitric oxide (NO) production in RAW 264.7 cells with $\mathrm{IC}_{50}$ values ranging from 13.4 to $17.8 \mu \mathrm{M}$ compared to positive controls (indomethacin $\mathrm{IC}_{50}=$ $24.0 \mu \mathrm{M}) .{ }^{85}$ Three pyrrolidine alkaloids, preussin I (231), (11R)/ (11S)-preussins J-K (232-233), were isolated from Aspergillus flocculosus 16D-1, a sponge-derived fungus. In lipopolysaccharide-induced THP-1 cells with $\mathrm{IC}_{50}$ values of 0.11 , 0.19 and $2.3 \mu \mathrm{M}$, respectively, these compounds displayed substantial inhibition against IL-6 production. ${ }^{86}$ Asperversiamides B-C (234-235) and F-G (236-237), four linearly fused prenylated indole alkaloids, were isolated from Aspergillus versicolor, a marine-derived fungus. The anti-inflammatory activities of these alkaloids were all tested, exhibiting potential iNOS inhibitory activities and inhibited the release of NO in LPSinduced RAW 264.7 with IC $_{50}$ values, ranged between 5.39 and $9.95 \mu \mathrm{M}$ (iNOS) and between $17.24 \pm 1.32$ and $25.09 \pm 2.21 \mu \mathrm{M}$ (NO release). ${ }^{87}$ All anti-inflammatory marine-derived Aspergillus metabolites are depicted in Fig. 3, 7-9.

\section{Antidiabetic activity}

Two new lumazine-containing peptides, terrelumamides A (238) and B (239), were obtained from Aspergillus terreus FA009 fungal strain cultivated from marine sediments, Jeju Island, Korea. These peptides improved insulin sensitivity that was tested in an adipogenesis model using stem cells of human bone marrow mesenchymal. Moreover, the peptides showed fluorescence changes from binding to DNA, indicating their possible applications for DNA sequence recognition. ${ }^{88}$ Flavipesolides A-C (240-242), three butenolide derivatives, in addition to 7 compounds; 5-[(3,4-dihydro-2,2-dimethyl-2 $H$-1-benzopyran-6-yl) methyl]-3-hydroxy-4-(4-hydroxyphenyl)-2(5H)furanone (243), aspernolide A (244), emodin (245), geodin hydrate (143), methyldichloroasterrate (246), monomethylosoic acid (139), epicoccolide B (30), were isolated from the Aspergillus flavipes HN4-13 fungus grown from a sediment sample in the coastal region of Lianyungang, China. The noncompetitive alphaglucosidase inhibitors $\left(K_{\mathrm{i}} / \mathrm{IC}_{50}\right.$ values $=0.43 / 34,2.1 / 37,0.79$ / 19 , and $2.8 / 90 \mu \mathrm{M}$, respectively) were 5 -[(3,4-dihydro-2,2dimethyl-2H-1-benzopyran-6-yl)methyl]-3-hydroxy-4-(4-hydroxyphenyl)-2(5H)furanone (243), aspernolide A (244), emodin (245) and methyldichloroasterrate (246). Mixed alphaglucosidase inhibitors with $K_{\mathrm{i}} / \mathrm{IC}_{50}$ values of $(2.5,19) / 44,(3.4$, $14) / 57,(9.2,4.7) / 95,(6.3,5.5) / 55,(1.4,0.60) / 9.9$, and $(2.5,7.2) / 33$ $\mu \mathrm{M}$, respectively $\left(\mathrm{IC}_{50} 79 \mu \mathrm{M}\right.$ for acarbose and $101 \mu \mathrm{M}$ for 1 deoxynojirimycin) are the compounds flavipesolides A-C (240242), geodin hydrate (143), monomethylosoic acid (139), and epicococcolide B (30). ${ }^{\mathbf{9}}$

A bisabolone sesquiterpene, deoxy-7,14-didehydrosydonol (214) was also evaluated for its $\alpha$-glucosidase inhibitory activity. This sesquiterpene displayed strong inhibitory activity against $\alpha$-glucosidase with $\mathrm{IC}_{50}$ value of $7.5 \mu \mathrm{M} .{ }^{79}$ Diketopiperazine dimer alkaloids, SF5280-415 (247) and SF5280-451 (248) were isolated from the marine-derived fungus Aspergillus sp. SF5280 (EtOAc extract) by various chromatographic methods. These alkaloids showed inhibitory effects towards PTP1B activity (for diabetes and obesity) with $\mathrm{IC}_{50}=12.9 \pm 0.7 \mu \mathrm{M} .^{90}$ $( \pm)$-tylopilusin D (249), a racemate of a diphenolic derivative, a phenalenone, funalenone (250), four polyketide naphthopyrones, rubrofusarin B (109), TMC-256A1 (251), aurasperone F (252), and fonsecin (253), together with malformin A1 (254), were isolated from Aspergillus sp. SF-5929, a marine-derived fungal strain. These isolates were evaluated for their inhibitory effects against protein tyrosine phosphatase 1B (PTP1B) activity, resulting in inhibition of PTP1B activity with $\mathrm{IC}_{50}$ values ranging between 3.3 and $8.1 \mu \mathrm{M} .{ }^{91}$

Butenolide derivatives $( \pm)$-asperteretal D (255), asperteretal E (256), flavipesolides B-C (241-242), butyrolactones I (207), II 
<smiles>CCCCCC(=O)/C=C/C(=O)O</smiles>

(174)<smiles>CCC(=O)O[C@H]1C(=O)[C@]2(C)[C@@H](CC[C@H]3/C(=C(\CCC=C(C)C)C(=O)O)[C@H](OC(C)=O)C[C@]32C)[C@@]2(C)CCC(=O)[C@H](C)[C@@H]12</smiles><smiles>Cc1cc(O)cc(Oc2cc(O)cc(C)c2C[C@H](O)C(C)(C)O)c1</smiles>

(182)<smiles>CCCCCCCCCCc1c[nH]c2ccccc12</smiles>

(186)<smiles>COC(OC)c1ccc2c(c1O)C(=O)c1ccccc1C2=O</smiles>

(190)<smiles>C=C(C)[C@H](O)Cc1c(C)cc(O)cc1Oc1cc(C)cc(O)c1</smiles>

(175)

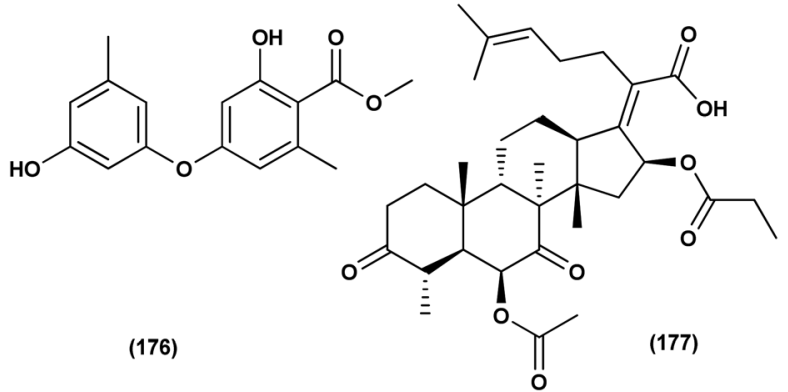<smiles>COC(C)(C)[C@@H](O)Cc1c(C)cc(O)cc1Oc1cc(C)cc(O)c1</smiles>

(179)<smiles>CC(C)=CCc1c(C)cc(O)cc1Oc1cc(C)cc(O)c1</smiles><smiles>Cc1cc(O)cc(Oc2cc(O)cc(C)c2CC(=O)C(C)C)c1</smiles>

(180)

(181)<smiles>Cc1cc(O)cc(Oc2cc(O)cc(C)c2C[C@H](O)C(C)(C)O)c1</smiles>

(183)<smiles>CC(=O)O[C@@H](Cc1c(C)cc(O)cc1Oc1cc(C)cc(O)c1)C(C)(C)O</smiles>

(184)<smiles>O=C(c1ccc(O)cc1)c1nc2ccccc2c(=O)[nH]1</smiles>

(188)<smiles>C[C@@H]1N[C@H]2N(C1=O)c1ccccc1[C@@]2(O)C[C@H](C(=O)O)n1cnc2ccccc2c1=O</smiles>

(185)<smiles>COC(=O)[C@H](C)CC/C=C(/C)c1ccc(C)c(O)c1O</smiles>

(189)

(187)<smiles>CC(C)=CCc1c(C)cc(O)c(CC=C(C)C)c1Oc1cc(C)cc(O)c1</smiles><smiles>CC(C)=CCc1c(C)cc(O)cc1Oc1cc(C)cc(O)c1</smiles><smiles>CC(C)=CCc1c(O)cc(C)cc1Oc1cc(C)cc(O)c1</smiles>

Fig. 11 Chemical structure of compounds 174-193.

(257), and 5-[(3,4-dihydro-2,2-dimethyl-2H-1-benzopyran-6-yl)methyl]-3-hydroxy-4-(4-hydroxyphenyl)-2(5H)-furanone

(258), were obtained from the marine-derived sponge Phakellia fusca fungus Aspergillus terreus. Those butenolides exhibited significant inhibitory activities against $\alpha$-glucosidase with $\mathrm{IC}_{50}$ values of $8.65 \pm 0.4-9.98 \pm 0.8,13.36 \pm 1.1,10.3 \pm 0.6,7.63 \pm 0.4$, $14.18 \pm 1.03$, and $11.65 \pm 0.7 \mu \mathrm{M}$, respectively (acarbose, positive control with an $\mathrm{IC}_{50}$ value of $\left.320 \mu \mathrm{M}\right) .{ }^{92}$ A butenolide derivative, 
<smiles>C[C@@H]1NC(=O)c2ccccc2-n2c1nc1ccccc1c2=O</smiles>

(194)<smiles>C=C[C@]1(C)CCc2c(c(O)cc3c2CCCC3(C)C)C1</smiles>

(195)<smiles>C=C[C@]1(C)C=C2C(=O)C=C3C(C)(C)CCC[C@]3(O)[C@@]2(O)CC1</smiles>

(196)<smiles>C=C[C@]1(C)C=C2C(=O)C=C3[C@@H](O)CC[C@]2(O)CC[C@H]3C1(C)C</smiles>

(197)<smiles>C=C[C@]1(C)CCc2c3c(cc(O)c2[C@@H]1O)C(C)(C)[C@@H](O)CC3</smiles>

(198)<smiles>C=C[C@]1(C)CCc2c3c(cc(O)c2[C@@H]1O)C(C)(C)[C@@H](O)CC3</smiles>

(199)<smiles>COC(OC)c1ccc2c(c1O)C(=O)c1ccccc1C2=O</smiles><smiles>C=C(/C=C/[C@H](C)[C@H]1CCC2=C3C=CC4=CC(=O)CC[C@]4(C)[C@H]3CC[C@@]21C)C(C)C</smiles><smiles>CC(C)[C@H](C)/C=C/[C@@H](C)[C@@]1(C)CC[C@]2(C)C3=CC(=O)O[C@@]3(O)CC[C@@]21C</smiles><smiles>CC(C)C(C)/C=C/C(C)[C@H]1CC[C@H]2/C(=C\C(=O)O[C@]3(C)CCC=CC3=O)C(=O)CC[C@@]21C</smiles>

(200)<smiles>COC(=O)[C@]1(Cc2ccc(O)c(CC=C(C)C)c2)OC(=O)C(OC)=C1c1ccc(O)cc1</smiles>

(204)<smiles>COC(=O)[C@]1(Cc2ccc(O)c(CC3OC3(C)C)c2)OC(=O)C(O)=C1c1ccc(O)cc1</smiles>

(208)<smiles>C[C@@H]1Cc2c(Cl)cc(C(=O)N[C@@H](Cc3ccccc3)C(=O)OCC(O)C(O)CO)c(O)c2C(=O)O1</smiles>

(209)

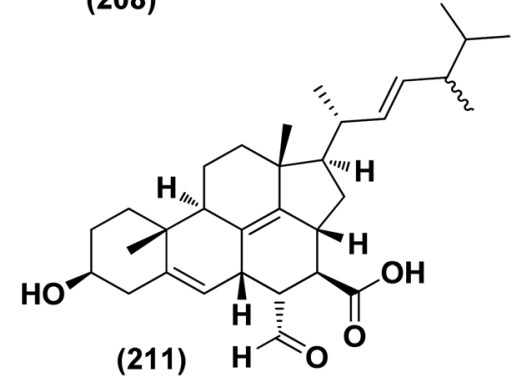<smiles>[Z12]#CCCCC1=C(c2ccc(O)cc2)C(=O)NC1=O</smiles><smiles>COC(=O)[C@]1(Cc2ccc(O)cc2)OC(=O)C(OC)=C1c1ccc(O)cc1</smiles>

(205)<smiles>O=C1C=C(c2ccc(O)cc2)[C@H](Cc2ccc(O)cc2)O1</smiles>

(206)<smiles>COC(=O)[C@]1(Cc2ccc(O)c(CC=C(C)C)c2)OC(=O)C(O)=C1c1ccc(O)cc1</smiles>

(207)

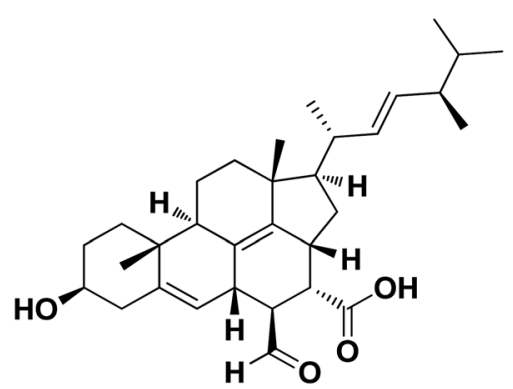

(210)<smiles>[R14][R11]</smiles>

(213)

Fig. 12 Chemical structure of compounds 194-213.

versicolactone $\mathrm{G}$ (222), was isolated from a coral-associated Aspergillus terreus fungus. An inhibitory potential with an $\mathrm{IC}_{50}$ value of $104.8 \pm 9.5 \mu \mathrm{M}$ (positive control acarbose $\mathrm{IC}_{50}=154.7 \pm$
$8.1 \mu \mathrm{M}$ ) was tested for alpha-glucosidase inhibitory activity of this isolate. $^{\mathbf{8 4}} \mathrm{A}$ meroterpenoid identified as $(R, E)$-3-(2,2-dimethylchroman-6-yl)-4-hydroxy-5-((2-(2-hydroxypropan-2-yl)-2,3- 
<smiles>C=C(CCCC(C)C)c1ccc(CO)cc1O</smiles>

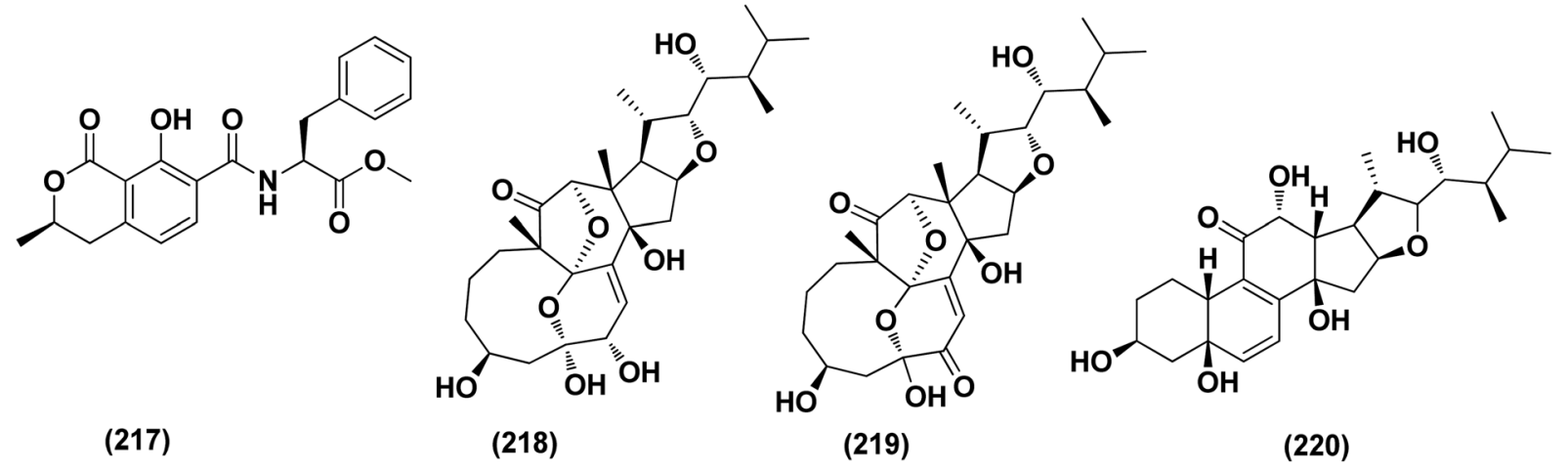<smiles>C=C(C)/C=C/c1cccc2c(C/C(=N/O)C(=O)OC)c[nH]c12</smiles>

(221)

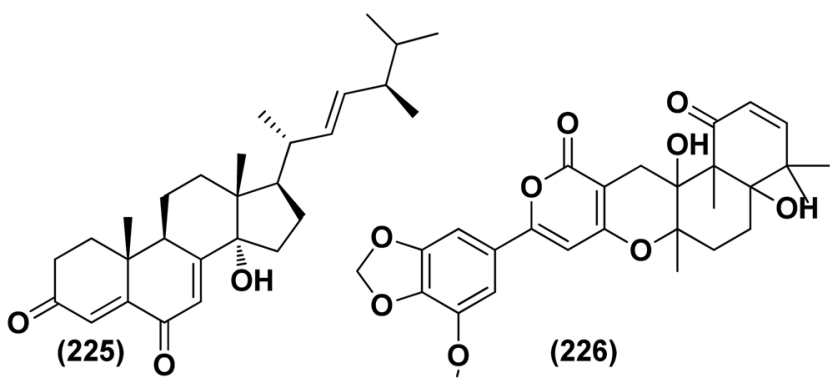

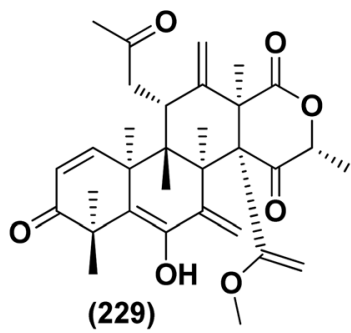

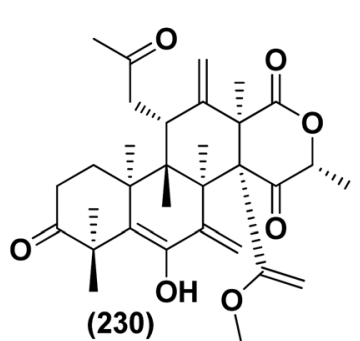<smiles>C/C(=C\CCO)CC/C=C(\C)CCCO</smiles><smiles>COC(=O)c1cc(OC)c(OC)c(OC)c1NC(=O)c1ccccc1NC(=O)c1cccnc1</smiles>

(224)

(223)

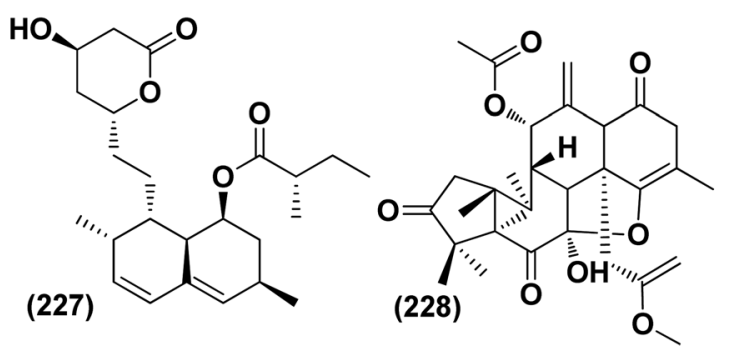<smiles>CCC(O)CCCCCC[C@@H]1CC(O)C(Cc2ccccc2)N1C</smiles>

(231)

Fig. 13 Chemical structure of compounds 214-231.

dihydrobenzofuran-5-yl)methylene)furan-2(5H)-one (259), a halogenated furanone, rubrolide $S(7)$ and a butenolide derivative, butyrolactone I (207), were isolated from Aspergillus terreus
OUCMDZ-2739 upon chemical-epigenetic culture with $10 \mathrm{mM}$ trichostatin A (TSA). These compounds demonstrated greater inhibition of alpha-glucosidase than acarbose and 1- 
<smiles>CC[C@H](O)CCCC[C@@H]1C[C@H](O)[C@H](Cc2ccccc2)N1C</smiles>

(232)

(233)<smiles>C=CC(C)(C)c1[nH]c2cc3c(cc2c1C[C@@H]1NC(=O)[C@@H]2CCCN2C1=O)C=CC(C)(C)O3</smiles>

(236)<smiles>COC(=O)c1ccccc1NC(=O)[C@H](CO)NC(=O)c1cnc2c(n1)c(=O)[nH]c(=O)n2C</smiles>

(239)<smiles>CC1(C)CCc2cc(CC3=C(c4ccc(O)cc4)[C@@](O)(C(=O)O)OC3=O)ccc2O1</smiles>

(242)<smiles>Cc1cc(O)c2c(c1)C(=O)c1cc(O)cc(O)c1C2=O</smiles>

(245)<smiles>C=CC(C)(C)c1[nH]c2cc3c(cc2c1/C=C1\NC(=O)[C@@H]2CCCN2C1=O)C=CC(C)(C)O3</smiles>

(237)

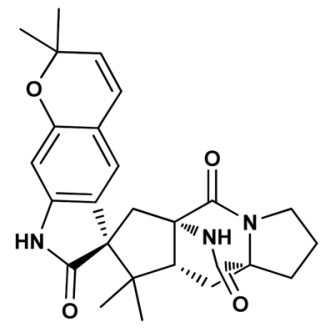

(234)<smiles>CC1(C)C=Cc2cc3c(cc2O1)NC(=O)[C@]31C[C@@]23C[C@H]4CCCN4C(=O)[C@]2(CC3=O)C1(C)C</smiles>

(235)<smiles>COC(=O)c1ccccc1NC(=O)[C@@H](NC(=O)c1cnc2c(n1)c(=O)[nH]c(=O)n2C)[C@@H](C)O</smiles>

(238)<smiles>COC(=O)[C@]1(O)OC(=O)C(Cc2ccc3c(c2)CCC(C)(C)O3)=C1c1ccc(O)cc1</smiles><smiles>CC1(C)CCc2cc(CC3OC(=O)C(O)=C3c3ccc(O)cc3)ccc2O1</smiles><smiles>COC(=O)[C@]1(Cc2ccc3c(c2)CCC(C)(C)O3)OC(=O)C(O)=C1c1ccc(O)cc1</smiles>

(243)

(244)<smiles>COC(=O)c1cc(O)cc(OC)c1Oc1c(Cl)c(C)c(Cl)c(O)c1C(=O)OC</smiles>

Fig. 14 Chemical structure of compounds 232-247.

deoxynojirimycin (positive controls) with $\mathrm{IC}_{50}$ values of 24.8, 1.2, 61.6, 555.1 and $191.7 \mu \mathrm{M}$, respectively. Furthermore, the enzyme kinetics analysis suggested that rubrolide $S$ (7) was an anticompetitive inhibitor (1.42 $\mu \mathrm{M} K_{\mathrm{i}}$ value).$^{13}$ Versicolactone $\mathrm{G}(\mathbf{2 2 2})$ was also tested for alpha-glucosidase inhibitory activity. This isolate demonstrated high inhibitory potency $\left(\mathrm{IC}_{50}\right.$ value $=104.8 \pm 9.5$ $\mu \mathrm{M})$, whilst $\left(\mathrm{IC}_{50}\right.$ of acarbose positive control $\left.=154.7 \pm 8.1 \mu \mathrm{M}\right){ }^{93}$ Two phenolic bisabolane sesquiterpenoids (E)-3-(3-hydroxy-4-(6- 
<smiles>C=CC(=C)O</smiles>

(248)<smiles>COc1cc(OC)c2c(O)c3c(=O)cc(C)oc3c(-c3c(O)cc4cc5c(c(O)c4c3OC)C(=O)CC(C)(O)O5)c2c1</smiles>

(249)<smiles>COC1=C(O)c2c(O)cc(C)c3c(O)cc(O)c(c23)C1=O</smiles>

(250)<smiles>COc1cc(=O)cc2cc3oc(C)cc(O)c3c(O)c12</smiles>

(251)

(253)<smiles>CCC(C)C(NC(=O)C(CC(C)C)NC(=O)C1NC(=O)C2CSSCC1NC(=O)C(C(C)C)NC2=O)C(=O)NC(CC(C)C)C(=O)NC1CSSCC1c1ccc(O)cc1</smiles>

(254)

(255)<smiles>COC(=O)[C@]1(Cc2ccc(O)cc2)OC(=O)C(O)=C1c1ccc(O)cc1</smiles>

(256)<smiles>C/C(=C\CCC(C)C)c1ccc(Cc2cc(C)cc(O)c2C)cc1O</smiles>

(260)

(257)<smiles>CC1(C)CCc2cc(C3=C(O)/C(=C\c4ccc5c(c4)C[C@H](C(C)(C)O)O5)OC3=O)ccc2O1</smiles>

(258)

(259)<smiles>CC(C)CCCC(C)(O)c1ccc(COC(=O)c2ccc(C(C)(O)CCCC(C)C)c(O)c2)cc1O</smiles>

(261)<smiles>Cc1cc(O)cc(Oc2cc(C)cc(OCc3ccc([C@@](C)(O)CCCC(C)C)c(O)c3)c2)c1</smiles>

(263)<smiles>C/C=C(\C)Oc1cc(C)c(Cc2ccc(C(C)(C)CCCC(C)C)c(O)c2)c(O)c1</smiles><smiles>O</smiles>

(262)

Fig. 15 Chemical structure of compounds 248-264.

methylhept-2-en-2-yl)benzyl)-2,5-dimethylphenol (260) and peniciaculin B (261) and derivatives containing phenolic bisabolane sesquiterpenoid and diphenyl ether units namely, peniciaculin A (262) and expansol D (263), were isolated from the Kandelia obovata-endophytic fungus Aspergillus flavus QQSG-3. All metabolites were tested for their alpha-glucosidase inhibitory action, showing potent inhibitory effects with $\mathrm{IC}_{50}$ values of $4.5,3.1,1.5$, and $2.3 \mu \mathrm{M}$, respectively. ${ }^{94}$ 
The biphenyl derivatives diorcinol E (181), diorcinol J (175) and diorcinol (18), were isolated from the marine Aspergillus versicolor OUCMDZ-2738 fungus in chemical-epigenetic $10 \mu \mathrm{M}$ vorinostat cultures (SAHA). These biphenyls displayed alphaglucosidase inhibitory activity with $\mathrm{IC}_{50}$ values of $117.3,275.3$ and $117.3 \mu \mathrm{M}$, respectively. Both diorcinols E (181) and J (175) displayed better $\alpha$-glucosidase inhibitory effect than the positive control acarbose $\left(\mathrm{IC}_{50}=255.3 \mu \mathrm{M}\right) .{ }^{66}$ All antidiabetic marinederived Aspergillus metabolites are depicted in Fig. 2, 4, 7-9 and 11-15.

\section{Antiviral activity}

A number of phenolic compounds including two anthraquinones, aspergilols $\mathrm{H}-\mathrm{I}$ (264-265), in addition to an anthraquinone compound, coccoquinone A (266), were identified from the fungus $A$. versicolor SCSIO 41502 (=DFFSCS010), a deep-seaderived strain that had been recovered from the South China Sea (marine sediment sample). Compounds aspergilol H (264), I (265) and coccoquinone A (266) displayed strong antiviral activity against herpes simplex virus types 1 (HSV-1) with $\mathrm{EC}_{50}$ values of $4.68,6.25$, and $3.12 \mu \mathrm{M}$, respectively. ${ }^{95}$

Asteltoxins E (267) and F (268) polyketides were obtained from Aspergillus sp. SCSIO XWS02F40, a marine sponge-derived fungus. Asteltoxin E (267) and F (268) demonstrated potent antiviral activity against influenza virus A subtype H3N2 (A/ $\mathrm{H} 3 \mathrm{~N} 2$ ) with the very low $\mathrm{IC}_{50}$ values of $6.2 \pm 0.08$ and $8.9 \pm 0.3$ $\mu \mathrm{M}$, respectively. Furthermore, asteltoxin $\mathrm{E}$ also revealed inhibitory activity against influenza virus A subtype H1N1 (A/H1N1) with an $\mathrm{IC}_{50}$ value of $3.5 \pm 1.3 \mu \mathrm{M} .{ }^{96}$ A meroterpenoid, named austalide $\mathrm{U}$ (269) was isolated from the sponge-derived Aspergillus aureolatus HDN14-107 fungus. Austalide U (269) revealed antiviral activity against $\mathrm{A} / \mathrm{H} 1 \mathrm{~N} 1$, with $\mathrm{IC}_{50}$ values of $90 \mu \mathrm{M} .{ }^{97}$ Two prenylated benzaldehyde derivatives, namely isodihydroauroglaucin (15) and flavoglaucin (16) were isolated from the fungus Aspergillus ruber collected from the Xisha Islands. The two benzaldehyde derivatives showed significant antiviral activity against HSV-1 virus. ${ }^{98}$ Three xanthones, namely methyl-(2-chloro1,6-dihydroxy-3-methylxanthone)-8-carboxylate (270), methyl-(4chloro-1,6-dihydroxy-3-methylxanthone)-8-carboxylate (271) and methyl-(1,6-dihydroxy-3-methylxanthone)-8-carboxylate (272), were isolated from Aspergillus iizukae (coastal saline soil-derived). These xanthones were evaluated for their antiviral activity, and methyl-(4-chloro-1,6-dihydroxy-3-methylxanthone)-8-carboxylate (271) exhibited definitely strong activity towards herpes simplex virus types 1 (HSV-1), 2 (HSV-2) and A/H1N1 with IC $_{50}$ values of 21.4, 76.7 and $44.6 \mu \mathrm{M}$, respectively, which suggested that it was worth to further study this xanthone as a potential lead compound. ${ }^{99}$

Two xanthones, 2-hydroxy-1-(hydroxymethyl)-8-methoxy-3methyl-9H-xanthen-9-one (273) and 2-hydroxy-1-(hydroxymethyl)7,8-dimethoxy-3-methyl-9H-xanthen-9-one (274), two anthraquinones, questin (133) and emodic acid (275) and a dibenzofurane, 3,7-dihydroxy-1,9-dimethyldibenzofuran (276), were isolated from the fungus Aspergillus sydowii SCSIO 41,301 collected from the sponge Phakellia fusca. All metabolites were tested for their antiviral activity. They displayed prominent selective inhibitory activities against two subtypes of influenza A virus, including $\mathrm{A} /$ FM-1/1/47 (H1N1) and A/Puerto Rico/8/34 (H1N1), with $\mathrm{IC}_{50}$ values varying between $2.17 \pm 1.39$ and $4.70 \pm 1.11 \mu \mathrm{M}$. The dibenzofurane compound also displayed obvious selective inhibitory activities against A/Aichi/2/68 (H3N2) with $\mathrm{IC}_{50}$ value of $1.24 \pm 0.14 \mu \mathrm{M}^{100} \mathrm{~A}$ meroterpenoid, aperterpene $\mathrm{N}$ (277), was isolated and identified from Aspergillus terreus EN-539, one of marine algal-derived endophytic fungi. This meroterpenoid showed inhibitory activity against influenza neuraminidase $\left(\mathrm{IC}_{50}\right.$ $=18.0 \mathrm{nM}) .{ }^{54}$ All antiviral marine-derived Aspergillus metabolites are depicted in Fig. 1, 8, 15 and 16.

\section{Anti-oxidant activity}

A number of phenolic compounds including compounds, 6methylbenzene-1,2,4-triol (278), violaceol-II (279), cordyol C (64) and sydowiols B (280), E (281) and D (282) were separated from the deep-sea-derived fungus $A$. versicolor SCSIO 41502 (=DFFSCS010) that had been recovered from a marine sediment sample, the South China Sea. With $\mathrm{IC}_{50}$ values of 18.92$52.27 \mu \mathrm{M}$ against DPPH radicals, the phenolic isolates exhibited antioxidant activity greater than L-ascorbic acid. ${ }^{95}$ Application of the OSMAC approach through adding bromide containing salts $\left(\mathrm{CaBr}_{2}\right.$ and $\left.\mathrm{NaBr}\right)$ during fermentation of Aspergillus niger (marine-mudflat-derived fungus) resulted in the development of a brominated naphthopyranone, named 6,9-dibromoflavasperone and three compounds; TMC-256A1 (251), fonsecin (253) and aurasperone B (283). The marine mudflat (from which the fungus Aspergillus niger, was cultivated) had been collected at Suncheon Bay, Jeonnam Province, Korea, All the isolated compounds exhibited potent radical scavenging activity against DPPH (2,2-diphenyl-1-picrylhydrazyl), with $\mathrm{IC}_{50}$ values of 21, 25, $0.3,0.02$, and $0.01 \mu \mathrm{M}$, respectively. Compounds TMC-256A1 (251), fonsecin (253) and aurasperone B (283) were more potent than ascorbic acid (the positive control, $\mathrm{IC}_{50}=20.0$ $\mu \mathrm{M}){ }^{101}$

Seven phenolic compounds were purified from the marinederived fungus Aspergillus versicolor; cordyol C (64), methylgerfelin (284), violaceol II (279), 10-O-methylaverantin (285), lecanoric acid (286), 1-methylpyrogallol (287), and fumalic acid (288). The fungus $A$. versicolor (A-21-2-7) was cultured from the deep-sea sediments, Southern China Sea. The isolates were investigated for their TEAC (trolox equivalent antioxidant capacity). Cordyol C (64), lecanoric acid, 1-methylpyrogallol (287), and fumalic acid (288) were proved to possess stronger free-radical scavenging effects, about five folds than trolox (positive control). Furthermore, the Nrf2-regulated gene expression, as found in the Nrf2-dependent luciferase reporter gene assay, was potentially activated by cordyol C (64), methylgerfelin (284), violaceol II (279), 10-O-methylaverantin (285) and lecanoric acid (286). ${ }^{102}$ 2-Pyrone derivatives, sydowiones A-B (289-290), were isolated from Aspergillus sydowii SCSIO 00305, a marine-derived fungus. They showed antioxidant activity against 2,2-diphenyl-picrylhydrazyl (DPPH) radicals with $\mathrm{IC}_{50}$ values of 46.0 and $46.6 \mathrm{lM}$, respectively. ${ }^{103}$ The cultured fungus Aspergillus europaeus WZXY-SX-4-1 (EtOAc extract) isolated from the marine-derived sponge Xestospongia testudinaria, was 
<smiles>C[C@H](O)CCC(CO)c1c(O)cc2c(c1O)C(=O)c1c(O)cc(O)cc1C2=O</smiles>

(265)<smiles>CC(=O)CCC(COC(C)=O)c1c(O)cc2c(c1O)C(=O)c1c(O)cc(O)cc1C2=O</smiles>

(266)<smiles>CC[C@H]1O[C@@H]2OC(/C=C/C=C/C=C/c3oc(=O)cc(OC/C=C(\C)C(=O)OC)c3C)C(O)[C@@]2(C)[C@@]1(C)O</smiles><smiles>COC(=O)/C(C)=C/COc1cc(=O)oc(/C=C/C=C/C=C/C2O[C@@H]3O[C@H](C)[C@@](C)(O)[C@]3(C)[C@H]2O)c1C</smiles>

(268)<smiles>C=C(OC)c1cc(O)cc2oc3c(Cl)c(C)cc(O)c3c(=O)c12</smiles>

(271)<smiles>C=C(OC)c1cc(O)cc2oc3cc(C)cc(O)c3c(=O)c12</smiles>

(272)<smiles>COc1c2c(c(C)c3c1C(=O)OC3)OC1(C)C[C@H](O)C3(O)[C@@H](CCC(=O)OC3(C)C)[C@@H]1C2</smiles><smiles>C=C(OC)c1cc(O)cc2oc3cc(C)c(Cl)c(O)c3c(=O)c12</smiles>

(269)

(270)<smiles>COc1cccc2oc3cc(C)c(O)c(CO)c3c(=O)c12</smiles>

(273)<smiles>COc1ccc2oc3cc(C)c(O)c(CO)c3c(=O)c2c1OC</smiles>

(274)<smiles>O=C(O)c1cc(O)c2c(c1)C(=O)c1cc(O)cc(O)c1C2=O</smiles>

(275)<smiles>Cc1cc(O)c(Cl)c2oc3c(Cl)c(O)cc(C)c3c12</smiles>

(276)

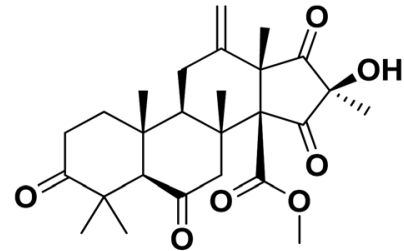

(277)<smiles>Cc1cc(O)cc(O)c1O</smiles>

(278)<smiles>Cc1cc(O)c(Oc2cc(C)cc(O)c2O)c(O)c1</smiles>

(279)<smiles>Cc1cc(O)c(O)c(Oc2cc(C)cc(O)c2Oc2cc(C)cc(O)c2O)c1</smiles><smiles>Cc1cc(O)c(Oc2cc(C)cc(O)c2Oc2c(O)cc(C(C)(C)C)cc2O)c(O)c1</smiles><smiles>Cc1cc(O)c(Oc2cc(C)cc(Oc3cc(C)cc(O)c3O)c2O)c(O)c1</smiles>

(281)

Fig. 16 Chemical structure of compounds 265-282.

evaluated, displaying radical scavenging activity (RSA). Therefore, polyketide derivatives, namely eurobenzophenone C (291), 3-de- $O$-methylsulochrin (105) and 14-de- $O$-methyl-5methoxysulochrin (292), were isolated from the mentioned bioactive fraction. These polyketides showed strong RSA against $\mathrm{DPPH}$ with $\mathrm{IC}_{50}$ values of $1.7 \pm 0.2,2.3 \pm 0.1$ and $5.4 \pm 0.1 \mu \mathrm{g}$ $\mathrm{mL}^{-1}$, respectively. ${ }^{43}$ 
<smiles></smiles>

(283)<smiles>COC(=O)c1c(C)cc(Oc2cc(C)cc(O)c2O)cc1O</smiles><smiles>CCCCC[C@@H](OC)c1c(O)cc2c(c1O)C(=O)c1c(O)cc(O)cc1C2=O</smiles>

(284)<smiles>Cc1cc(Cc2cc(Cc3cc(C)c(O)c(C)c3)c(O)c(O)c2O)cc(C)c1O</smiles>

(287)<smiles>COc1cc(/C=C/C(=O)O)ccc1O</smiles>

(288)<smiles>COC1=CC(OC)C(C(=O)c2c(O)cc(C)cc2O)C(C(=O)O)=C1</smiles>

(292)<smiles>COC(=O)[C@]1(Cc2ccc(O)c(CCC(C)(C)O)c2)OC(=O)C(O)=C1c1ccc(O)cc1</smiles>

\section{(285)}<smiles>CCC(C)[C@H](O)Cc1cc(O)c(C)c(=O)o1</smiles>

(289)
(290)<smiles>Cc1cc(O)c(C(=O)c2c(O)cc(O)cc2C(=O)O)c(O)c1</smiles><smiles>CCC(C)[C@H](O)Cc1oc(=O)c(C)c(O)c1C</smiles><smiles>COC(=O)CCN1Cc2c(O)c(O)c(O)c(C)c2C1=O</smiles>

(294)<smiles>COC(=O)[C@H](C)N1Cc2c(O)c(O)c(O)c(C)c2C1=O</smiles>

(295)<smiles>O=C1c2cc(O)cc(O)c2C(=O)c2c1cc1c(c2O)[C@@H]2[C@@H](OC[C@@H]2O)O1</smiles>

(296)<smiles>CCCCCC(O)c1c(O)cc2c(c1O)C(=O)c1c(O)cc(O)cc1C2=O</smiles>

(297)<smiles>CCCC/C=C/c1c(O)cc2c(c1O)C(=O)c1c(O)cc(O)cc1C2=O</smiles>

(298)

Fig. 17 Chemical structure of compounds 283-298.

Butenolide derivatives, asperteretal E (256), butyrolactone III (208) and aspernolide A (244), B (293), were isolated from the fungus Aspergillus terreus. SCSIO FZQ028, South China Sea deep-sea sediment. All the derivatives were evaluated for their antioxidative activities against DPPH, showing potent activities against DPPH $\left(\mathrm{IC}_{50}\right.$ ranging between 5.89 and $\left.10.07 \mu \mathrm{g} \mathrm{mL}^{-1}\right){ }^{104}$ Azacoccones C (294) and E (295), aza-epicoccone derivatives, were isolated from the marine-derived Aspergillus flavipes 
<smiles>C[C@]12CC[C@@H](O)[C@H](O1)c1c(cc3c(c1O)C(=O)c1c(O)cc(O)cc1C3=O)O2</smiles>

(299)<smiles>CCCCCCCCCCCC(=O)O</smiles>

(302)<smiles>Cc1cc(O)c(O)c(Oc2cc(C)cc(O)c2O)c1</smiles>

(306)<smiles>COc1c(-c2ccccc2)cc(OC)c2c1oc1cc(O)c(O)cc12</smiles>

(310)<smiles>C=CC(C)(C)c1[nH]c2cc(CC=C(C)C)ccc2c1/C=c1\[nH]c(=O)c(=C)[nH]c1=O</smiles>

(314)

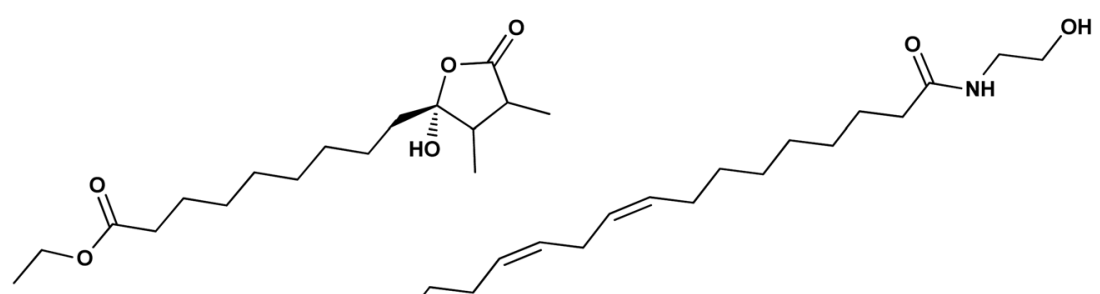

(300)<smiles>C=C[C@]1(C)CCC2=C(C(=O)C=C3C(C)(C)CCC[C@]32O)[C@@H]1OC</smiles>

(304)<smiles>O=C1C2Cc3c([nH]c4ccccc34)[C@@]1(CO)Nc1nc3ccccc3c(=O)n12</smiles>

(303)

(305)<smiles>CCCNCc1nnc(C)s1</smiles><smiles>COc1c(-c2ccc(O)cc2)cc(OC)c2c1oc1cc(O)c(O)cc12</smiles>

(308)

(309)<smiles>CN1C(=O)c2cccc3c(N(C)C)ccc(c23)C1=O</smiles><smiles>C=CC(C)(C)C1=Nc2cc(CC=C(C)C)ccc2/C1=C\c1[nH]c(=O)c(=O)[nH]c1O</smiles><smiles>C=CC(C)(C)c1[nH]c2ccccc2c1/C=c1\[nH]c(=O)c(=C)[nH]c1=O</smiles>

HO<smiles>Cc1cc(I)cc(Oc2cc(C)c(C(=O)OCC(O)CO)c(O)c2)c1</smiles><smiles>Cc1cc(CC(=O)C[C@H](C)O)c(C=O)c(O)c1C</smiles>

(315)

(316)

culture. These derivatives demonstrated substantial free radical scavenging effects that were greater than positive control trolox ( $\mathrm{IC}_{50}$ values of $4.0,2.4$ and $4.55 \mu \mathrm{g} \mathrm{mL}{ }^{-1}$ respectively). ${ }^{105}$ EtOAc extract of Aspergillus versicolor fungus derived from deep-sea sediments leading to the isolation of four anthraquinones, UCT1072M1 (296), averantin (297), averythrin (298) and 
<smiles>Cc1cc(O)cc(Oc2cc(C)cc(O)c2)c1</smiles>

(317)<smiles>Cc1cc(O)cc(Oc2cc(C)cc(O)c2O)c1</smiles>

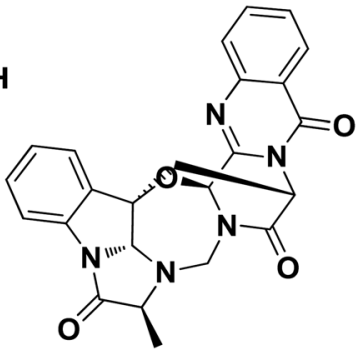

(319)

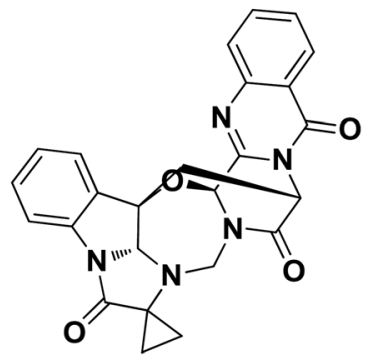

(320)<smiles>COC(=O)[C@@H]1C[C@@]2(O)c3ccccc3N3C(=O)C4(CC4)C(=O)N2[C@@H](OC)[C@@H](OC)N3C1=O</smiles>

(321)<smiles>CC(O)C(O)/C=C/C=C/C(=O)O[C@H]1C=C2COC(C)(C)OC[C@]2(O)[C@@]2(C)CCCC(C)(C)[C@]12O</smiles><smiles>CCCC1=C/C(=C/[C@@H](O)[C@H](C)O)OC1=O</smiles><smiles>CC(C)c1ccc(CO)c2ccc(C(=O)O)cc12</smiles>

(322)

(323)

(324)<smiles>C/C=C(/C)c1c(Cl)c(O)c(C)c2c1Oc1c(Cl)c(O)c(Cl)c(C)c1C(=O)O2</smiles>

(325)<smiles>C/C=C(\C)c1c(Cl)c(OC)c(C)c2c1Oc1c(Cl)c(O)c(C)c(C)c1C(=O)O2</smiles>

(326)<smiles>C/C=C(/C)c1c2c(c(C)c(O)c1C(=O)O)OC(=O)c1c(C)cc(O)cc1O2</smiles>

(327)<smiles>C/C=C(\C)c1c(Br)c(O)c(C)c2c1Oc1cc(O)c(Br)c(C)c1C(=O)O2</smiles>

(328)

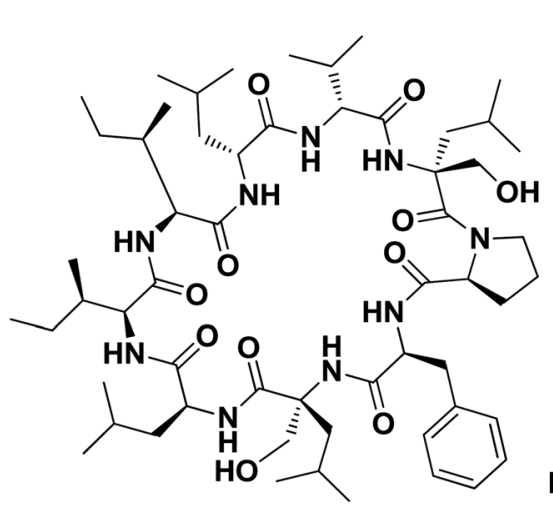

(329)

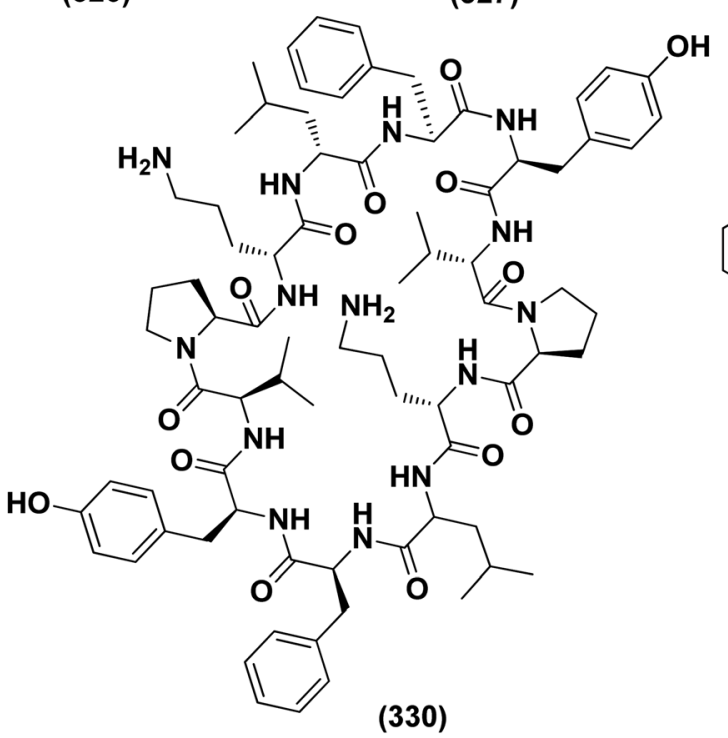<smiles>CC(C)[C@H]1NC(=O)[C@H](Cc2ccccc2)NC1=O</smiles><smiles>CCn1c(C(=O)O)cc2cc(O)c(O)cc21</smiles>

(332)

Fig. 19 Chemical structure of compounds 317-332.

nidurufin (299). These isolates potentially triggered the expression of Nrf2 (the nuclear factor E2-related factor 2), a transcription factor that consistent with oxidative stress by binding to ARE (the antioxidant response element) in the genes promoter coding for antioxidant proteins and enzymes for glutathione synthesis with $1.49 \pm 0.28,1.58 \pm 0.11,1.46 \pm 0.08$, 
and $1.41 \pm 0.05$ folds, respectively compared to control. ${ }^{106}$ All anti-oxidant marine-derived Aspergillus metabolites are depicted in Fig. 3, 12, 14, 15 and 16-18.

\section{Antifungal activity}

DEHP (115) also exhibited activity against Candida albicans fungus with inhibition diameter zone of $20 \mathrm{~mm} .{ }^{49}$ Reporting the bioassay-guided purification of bioactive fatty acid derivatives, a butenolide, namely sinulolide I (300) together with three common metabolites, (9Z,12Z)- $N$-(2-hydroxyethyl) octadeca9,12-dienamide (301), dodecanoic acid (302) and decanoic acid (303), were isolated from Aspergillus terreus SCSIO 41202 from the deep-sea sediment. These compounds displayed significant antifungal activity against Penicillium italicum (citrus postharvest pathogen) with MIC values around 0.125, 0.062, 0.031 and $0.062 \mathrm{mg} \mathrm{mL}^{-1}$, respectively. ${ }^{107} \mathrm{~A} 20$-nor-isopimarane diterpenoid epimer, aspewentin M (304), was isolated from Aspergillus wentii SD-310 fungus from the deep sea sediment. This compound was tested for plant-pathogenic fungi, showing potent activity against Fusarium graminearum. ${ }^{\mathbf{1 0 8}}$ An indole alkaloid, namely fumigatoside E (305) was purified from deepsea fungal Aspergillus fumigatus SCSIO 41012. In addition, it was evaluated for its antifungal inhibitory activities, showing potent antifungal effect towards Fusarium oxysporum f. sp. momordicae, with MIC of $1.56 \mu \mathrm{g} \mathrm{mL}{ }^{-1} .^{68}$

On the course of anti-saprolegniasis metabolites from numerous cultured broths of various deep-sea fungal strains, three diphenyl ethers, diorcinol (18), violaceol-I (306) and violaceol-II (279), were isolated from the deep-sea derived fungus Aspergillus sp. YK-76 originated from an Osedax sp. annelid. These compounds showed anti-S. parasitica activity, suggesting that diorcinol (18) and violaceol analogs could have their potential to be used as saprolegniasis preventing candidates. ${ }^{109}$ Chitinase enzyme (307) was produced from unconventional sources, the marine-derived fungus Aspergillus griseoaurantiacus KX010988 by solid state fermentation of potato shells. Chitinase enzyme (307) showed good antifungal activity against $F$. solani with inhibition zone diameter $=23 \pm$ $1.20 .^{52}$ An indoloditerpene, $(3 R, 9 S, 12 R, 13 S, 17 S, 18 S)$-2-carbonyl3-hydroxylemeniveol (126) was isolated from a marine-derived fungus Aspergillus versicolor ZZ761. This indoloditerpene showed antimicrobial activities with MIC value of $22.8 \mu \mathrm{M}$ against Candida albicans. ${ }^{17}$ Prenylated $p$-terphenyls, prenylterphenyllins $\mathrm{H}-\mathrm{J}$ (37-39), were isolated from the marinederived endophytic fungus Aspergillus candidus LDJ-5. The
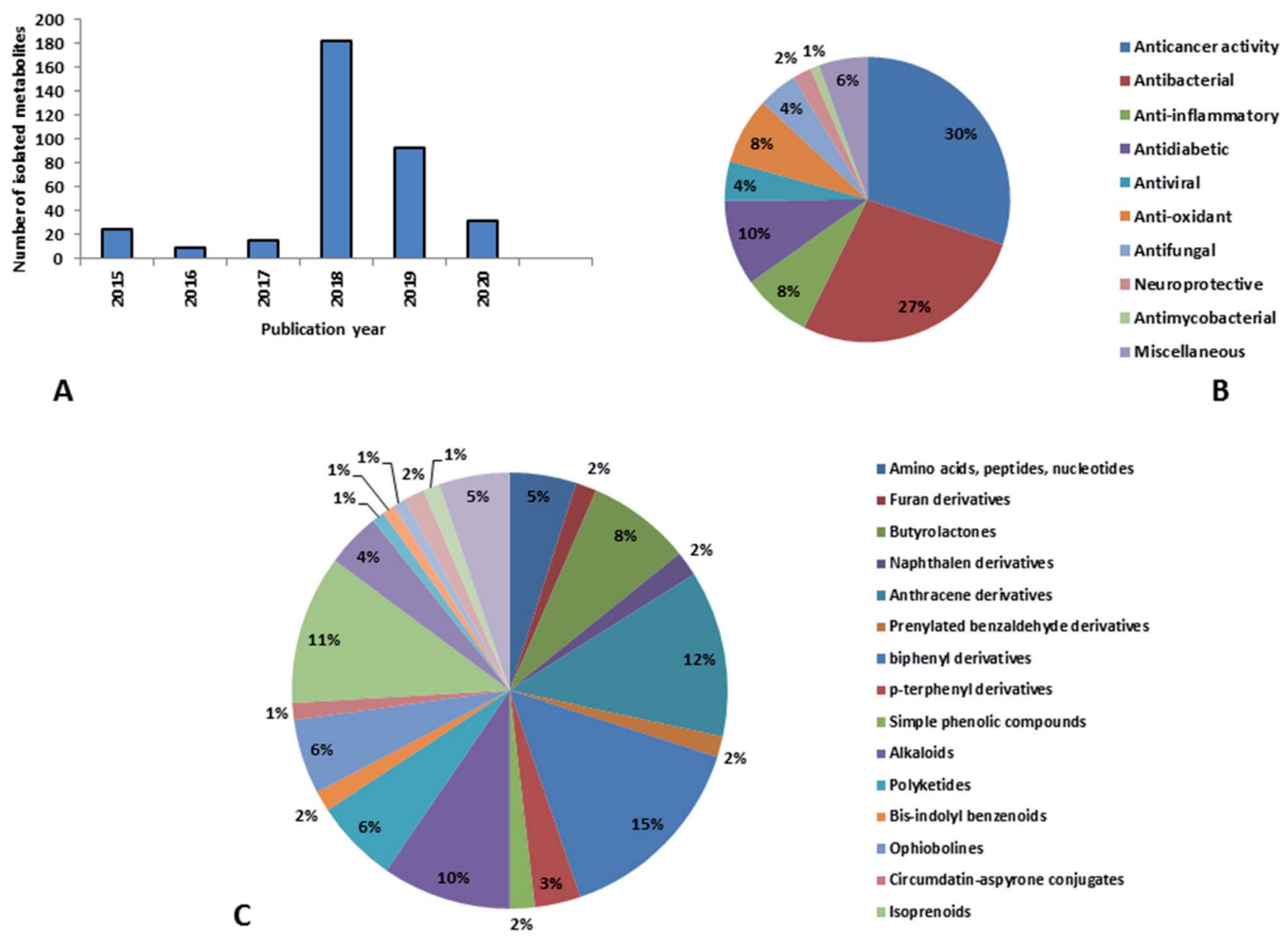

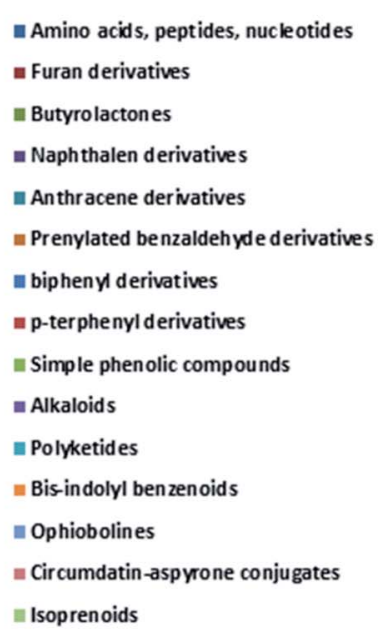

Fig. 20 (A) Natural products isolated from marine-derived genus Aspergillus according to the year of publication, (B) bioactivities of natural products derived from marine-derived genus Aspergillus, (C) secondary metabolites classes derived from marine-derived genus Aspergillus. 
three compounds are active as antimicrobials against Monilia albicans with $\mathrm{IC}_{50}$ values varying from 22 to $90 \mu \mathrm{g} \mathrm{mL} \mathrm{m}^{-1} \cdot{ }^{24} \mathrm{~A}$ study of the fungal strain described the isolation of a rare class of fungal metabolites, 20-nor-isopimarane diterpenoids, upon implementation of different fungal cultivation conditions. Aspewentins D (196), H (199), were obtained from the A. wentii SD-310 EtOAc extract. These compounds were tested against four plant pathogenic fungi for their antifungal activity and showed activity against $F$. graminearum, with MIC values of 2.0 and $4.0 \mu \mathrm{g} \mathrm{mL}{ }^{-1}$, which are smaller than that of the positive control amphotericin B (MIC $\left.=8.0 \mu \mathrm{g} \mathrm{mL}{ }^{-1}\right)$, respectively. ${ }^{73}$ All antifungal marine-derived Aspergillus metabolites are depicted in Fig. 1, 2, 7, 8, 12, 16 and 18.

\section{Neuroprotective activity}

An auroglaucin-derived compound, niveoglaucin A (308) and a prenylated benzaldehyde derivative, flavoglaucin (16), were isolated from the extract of Aspergillus niveoglaucus (a marine sediment-derived strain). The neuroprotective activity in 6OHDA-induced Parkinson's disease cell model was shown for both compounds, resulting in increased viability of 6-OHDAtreated cells by $20-25 \% .{ }^{110}$ The neuroprotective activities of diketopiperazine mactanamide (51) from Aspergillus flocculosus and prenylated $p$-terphenyls, candidusin A (309) and $4^{\prime \prime}$-dehydroxycandidusin A (310) from Aspergillus sp. KMM 4676, were evaluated in the paraquat (PQ)-induced Parkinson's disease (PD) and 6-hydroxydopamine (6-OHDA)- cell models. These metabolites protected Neuro2a cells against the 6-OHDA damaging influence to varying degrees, which might be realized via ROS scavenging pathway. Dehydroxylation at C- 4 " and C- 3 " remarkably increased neuroprotective activity and ROS scavenging of candidusin-related $p$-terphenyls in both the PQinduced PD and 6-OHDA-models. ${ }^{111}$ Four echinulin-related indolediketopiperazine alkaloids, namely (-)-Cryptoechinuline B (311), neoechinulin (312), and neoechinulins B-C (313314), were isolated from the fungus Aspergillus niveoglaucus (Vietnamese sediment-derived). (+)-Cryptoechinuline B (311) displayed neuroprotective activity in rotenone, paraquat- and 6OHDA-induced in vitro Parkinson's disease models. (-)-Cryptoechinulin B (311) and neoechinulin C (314) have shown substantial neuronal cell defense against paraquat-induced damage. In the 6-OHDA-induced model, neoechinulin (312) showed activity and neoechinulin B (313) exhibited cytoprotective activity in a rotenone-induced model. ${ }^{112}$ All neuroprotective marine-derived Aspergillus metabolites are depicted in Fig. 1, 3 and 18.

\section{Antimycobacterial activity}

Ergosterdiacids A (210) and B (211) were obtained from Aspergillus sp. DM29, one of mangrove-derived fungi (see Anti-

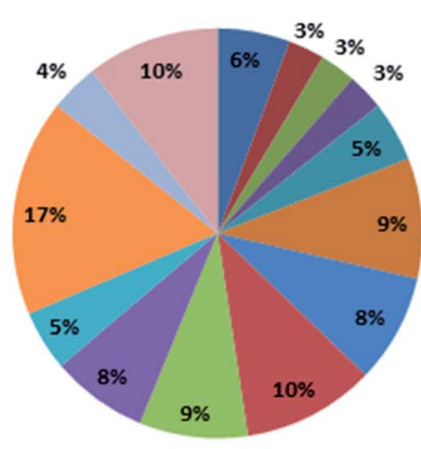

A

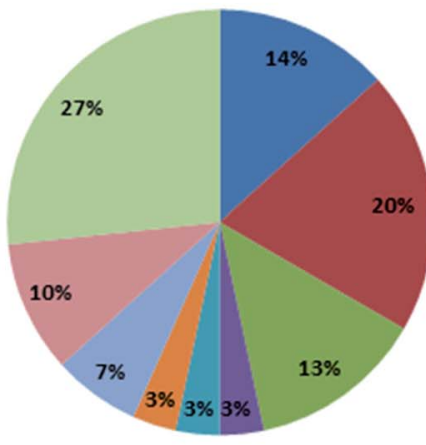

Amino acids

asteroids

Butenolides

- Sesquiterpenes

Anthraquinones

Fatty acids

Miscellaneous

Meroterpenoids

alkaloids

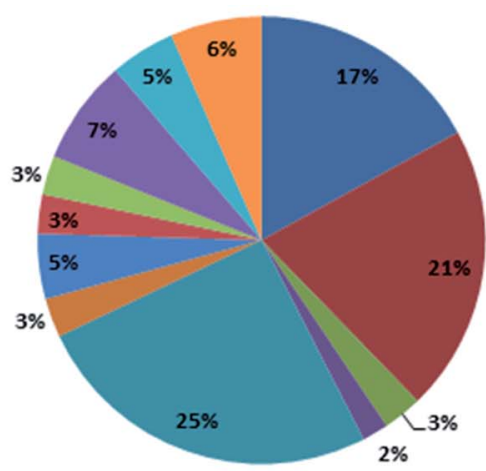

anthracene derivatives

- Steroids \& isoprenoids

= Citrinin analogues

- Peptides

Biphenyl derivatives

= Pyrazin-2(1H)-one derivatives

a Polyketides

a Prenylated p-terphenyls

= Diketomorpholine derivatives

alkaloids

= Butyrolactone derivatives

Other classes

B

C

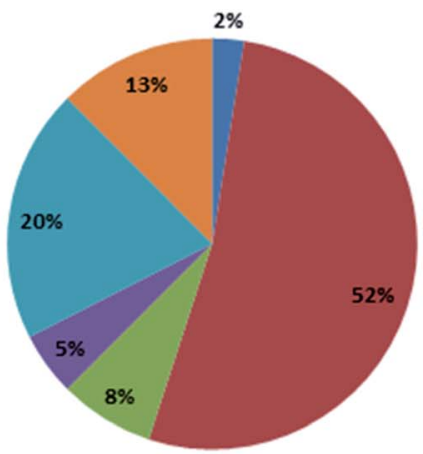

- Lumazine-containing peptides

- Butenolide derivatives

- Sesquiterpenes

- Diketopiperazine dimer alkaloids

Biphenyl derivatives

= Polyketides

Fig. 21 Distribution of metabolites (divided in chemical classes) isolated from marine-derived genus Aspergillus in (A) anticancer activity, (B) antibacterial activity, (C) anti-inflammatory activity and (D) antidiabetic activity. 


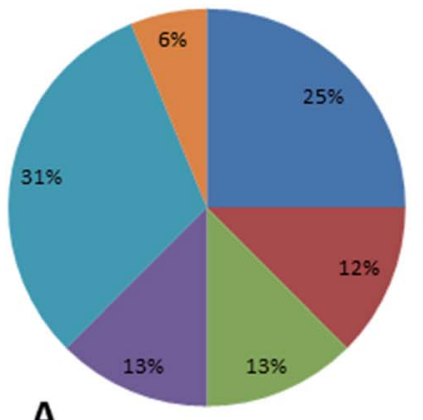

A

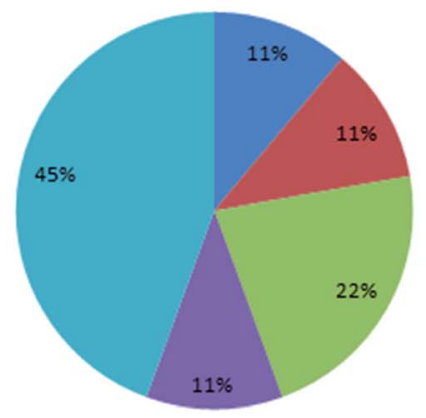

$=$ Au roglaucin-derived compounds

a Prenylated benzaldehyde derivatives

= Prenylated p-terphenyls

Diketopiperazines

=Echinulin-related ind ole-diketopiper azine alkaloids

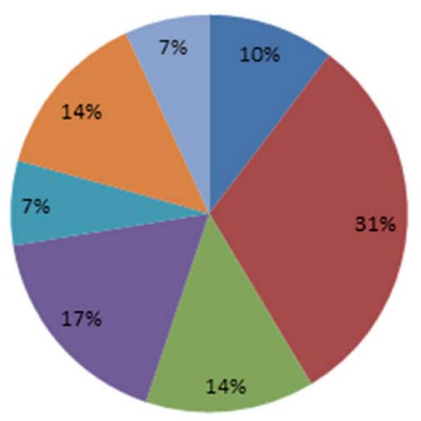

a Phenolic compounds

- Biphenyl derivatives

= Polyketide naph thopyranones

- Anthraquinone

an Pyrone derivatives

= Butenolide derivatives

Azacoccone derivatives

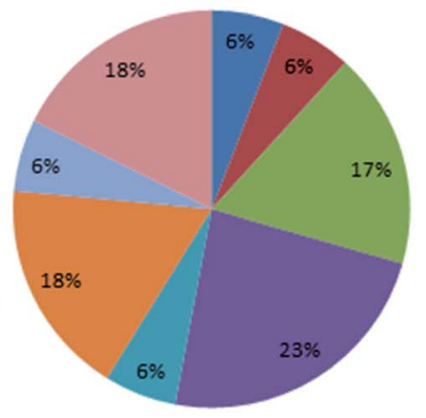

Phthalates

n Butenolides

an Fatty acids

n Diterpenes

In In lo alkaloids

a Biphenyl derivatives

n Thiazoles

In Prenylated p-terphenyls

C

Fig. 22 Distribution of metabolites (divided in chemical classes) isolated from marine-derived genus Aspergillus in (A) antiviral activity, (B) antioxidant activity, (C) neuroprotective activity and (D) antifungal activity.

inflammatory section). In the bioactivity assays, these steroids exhibited potential in vitro inhibition effect against MptpB (Mycobacterium tuberculosis protein tyrosine phosphatase B) with an $\mathrm{IC}_{50}$ value of 15.1 and $30.1 \mu \mathrm{M}$, respectively. The experimentations concerning inhibitory kinetic indicated that both steroids acted via a noncompetitive inhibition mechanistic pathway. ${ }^{77}$ Butyrolactone I (207), a polyketide was obtained from Aspergillus terreus SCSIO 41008 (a marine sponge-derived fungus). It showed significant inhibitory effects against MptpB, with the $\mathrm{IC}_{50}$ of $5.11 \pm 0.53 \mu \mathrm{mol} \mathrm{L} \mathrm{L}^{-1}$. This butyrolactone acted via a noncompetitive inhibition based on kinetic analysis. ${ }^{113}$ Prenylterphenyllin I (38), a prenylated $p$-terphenyl was isolated from the marine-derived endophytic fungus, Aspergillus candidus LDJ-5. This compounds was found to be antimicrobial against Mycobacterium phlei with $\mathrm{IC}_{50}$ value of 45 $\mu \mathrm{g} \mathrm{mL}^{-1} .^{24}$ All antimycobacterial marine-derived Aspergillus metabolites are depicted in Fig. 2 and 12.

\section{Miscellaneous activities}

A number of phenolic compounds including 4-carbglyceryl-3,3'dihydroxy-5, 5'-dimethyldiphenyl ether (315), sydowiols B (280), E (281) and D (282), and 2,4-dihydroxy-6-(4S-hydroxy-2oxopentyl)-3-methylbenzaldehyde (316), were separated from the A. versicolor SCSIO 41502 (=DFFSCS010), one of deep-seaderived fungal strains that had been recovered from a marine sediment sample, the South China Sea. These phenolic compounds exhibited significant antifouling activity towards a larval settlement Bugula neritina with $\mathrm{EC}_{50}$ values of 1.28, 2.61, $5.48,1.59$, and $3.40 \mu \mathrm{g} \mathrm{mL}{ }^{-1}$, respectively. ${ }^{95}$

Epigenetic modification of the marine-derived fungus Aspergillus sp. SCSIOW3 obtained from a deep marine sediment sample collected in the South China Sea, elicited the isolation of two compounds; diorcinal (317) and cordyol (318). The biomembrane defensive role of erythrocytes has been shown by these compounds. Algicidal action against Chattonella marina, an alga causing large-scale fish kills, was also seen with diorcinal (317). ${ }^{\mathbf{1 1 4}}$

Versiquinazolines A (319), B (320) and G (321), fumiquinazoline-type alkaloids, were separated from the gorgonian (Pseudopterogorgia sp.)-derived Aspergillus versicolor LZD-14-1 fungus, the South China Sea. These metabolites exhibited inhibitory activities towards thioredoxin reductase, with $\mathrm{IC}_{50}$ values of 20,12 and $13 \mu \mathrm{M}$, respectively. ${ }^{115}$ An artifact drimane derivative, 11,12-O-isopropylidene-6-epi-albrassitriol ester of (E,E)-6,7-dihydroxy-2,4-octadienoic acid (322) was isolated from Aspergillus ustus KMM 4664, a marine-derived fungus. This drimane exhibited significant inhibition effect of spermatozoa, fertilizing egg-cells of the Strongylocentrotus intermedius (sea urchin) with $\mathrm{IC}_{50}$ value of $21 \mu \mathrm{M} .{ }^{\mathbf{1 1 6}}$

A $\gamma$-lactone, aspergilactone A (323) and pericoterpenoid A (324), a naphthalene carboxylic acid derivative, were purified from the sponge-associated fungus Aspergillus sp. LS45. These metabolites were investigated in a variety of bioassays, and both metabolites showed strong inhibitory activity against the 


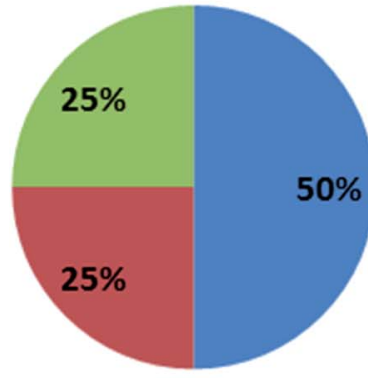

ateroids - Butyrolactones a Prenylterphenyllin

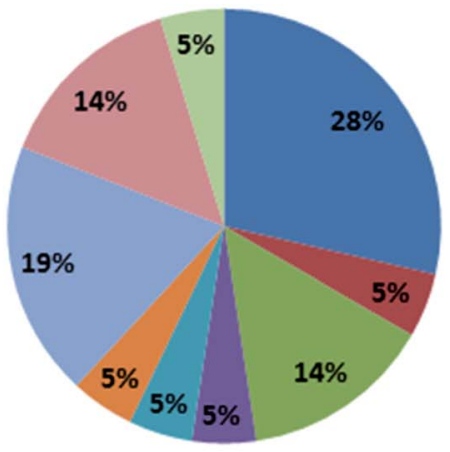

aiph enyl derivatives

n Benzaldehyde derivatives

a Fumiqu in azoline-type alkaloids

n Drimane derivatives

v-lactones

Naph thalene derivatives

= Depsidone derivatives

neptides

Indole derivatives

\section{A}

Fig. 23 Distribution of metabolites (divided in chemical classes) isolated from marine-derived genus Aspergillus in (A) antimycobacterial activity, (B) other activities.

Arabidopsis thaliana Columbia-0 lateral root growth at a concentration of $100 \mu \mathrm{M} .^{117}$ Depsidone derivatives, namely nornidulin (325), nidulin (326) and aspergillusidones A (327) and $\mathrm{F}$ (328), were isolated from the marine-derived fungus Aspergillus unguis. Nornidulin (325), nidulin (326) and aspergillusidones $\mathrm{F}$ (328) displayed potent larvicidality against brine shrimp with $\mathrm{IC}_{50}$ values of $12.8,4.5$ and $12.8 \mu \mathrm{M}$, respectively, indicating that plasma mutagenesis and chemical induction could be utilized as tools to the chemodiversity of fungi and to purify useful natural products. In addition, aspergillusidone A (327) inhibited acetylcholinesterase (AChE), with $\mathrm{IC}_{50}$ of 56.75 $\mu \mathrm{M}$. $^{118}$

Peptides, namely cyclo-(L-Leu-L-Pro) (329), cyclo-(L-Val-L-Pro) (330) and cyclo-(L-Phe-L-Val) (331), were isolated from $A$. sydowii very active extract $(84.5 \pm 2.2 \%$ of acethylcholinesterase inhibition), through using three different media (peptone $\left(12 \mathrm{~g} \mathrm{~L}^{-1}\right)$ and sucrose $\left(150 \mathrm{~g} \mathrm{~L}^{-1}\right)$ as sources of nitrogen and carbon, respectively). The three peptides were active as AChE inhibitors with a uniform $\mathrm{IC}_{50}$ value of $0.36 \pm 0.17, \mu \mathrm{mol} \mathrm{mL}{ }^{-1}$ for cyclo-(LLeu-L-Pro) (329) and cyclo-(L-Val-L-Pro) (330), which was approximately similar to the $\mathrm{IC}_{50}$ of galanthamine $(0.38 \pm 0.15$ $\left.\mu \mathrm{mol} \mathrm{mL}{ }^{-1}\right)$ and $\mathrm{IC}_{50}$ value of $1.13 \pm 0.32$ for cyclo-(L-Phe-L-Val) (331), showing how some changes in culturing conditions can modify the production of bioactive metabolites, which are silent in other conditions of cultivation. ${ }^{\mathbf{1 1 9}}$

In vitro UVB protection studies emphasizes DHICA (5,6dihydroxyindole-2-carboxylic acid) (332) isolated from the marine-derived fungus Aspergillus nidulans, significantly protected HaCaT cells from the action of UVB exposure through reducing cell apoptosis, maintaining the cellular integrity, scavenging the generated ROS, and consecutively downregulating the lipid peroxidation (LPO) and up-regulating the antioxidant enzyme catalase, SOD (superoxide dismutase) and GPx (glutathione peroxidase), respectively. Furthermore, experiments on gelatin zymography, cell cycle arrest analysis, and western blot analysis on TNF-alpha and COX-2, IHC (Immunohistochemistry) on $\mathrm{Bax}$ and $\mathrm{Bcl} 2$ (apoptotic markers) verify the protective role of DHICA (332). In addition, in vivo evaluations on $\mathrm{BALB} / \mathrm{c}$ mice were carried out and reproached with the sunscreen cream with SPF (sun protective factor) of 20. Skin sections analysis of experimental samples discovered an appreciable decline in the thickness of epidermis concerning the mice skin samples DHICA (332) pre-exposed followed by UVB exposure that was compared to control (UVB exposure alone). RT-PCR results on different inflammatory apoptotic markers also proposed that DHICA (332) possess UVB protective potential, suggesting to explore the possible application of DHICA (332), individually as a sun-protective principle for skin care. ${ }^{\mathbf{1 2 0}}$ All miscellaneous biological activities concerning marine-derived Aspergillus metabolites are depicted in Fig. 16, 18 and 19.

\section{Conclusion and future directions}

Natural products originating from the marine genus Aspergillus exhibited a large chemical diversity and important medicinal values, providing an untapped potential for medications and drug candidates. This marine-inspired genus has been a strong model since its discovery almost 50 years ago as a treasure trove of naturally derived drug candidates. The accumulation of hundreds of marine-derived Aspergillus strains worldwide, together with nearly 30 years of research power in both industry and academia, has created a resource enabling the biosynthesis of natural metabolites to be distinguished between closely related ecological strains. This rapprochement has already exposed the dynamics of microbial gene production and will go on to afford insights into the pathways for creating new structural diversity. The idea that novel microbial taxa inhabiting aquatic environments represent a promising origin for natural product exploration has been supported by detailed biochemical studies of the marine-derived genus Aspergillus. In aquatic environments, marine-derived Aspergillus strains have typically been isolated mainly from marine animals, such as sponges, ascidians and soft corals and sediments. In comparison, there were few samples of talented marine-derived species living in drastic areas. Subsequently, the interest in marine-derived Aspergillus species was growing, and became an essential 
source of chemical diversity particularly in the 2018 and 2019 (Fig. 20A).

In accordance with chemical diversity, no unique chemical class could be recognized from marine-derived Aspergillus spp., predominantly anthracene derivatives, biphenyl derivatives, alkaloids, isoprenoids and butyrolactones (Fig. 20C). Of the about 2000 typical bioactive metabolites from marinederived Aspergillus, 332 have been reported to exhibit different activities (Fig. 1-19, 20B). Most metabolites of marine Aspergillus have demonstrated excellent anti-cancer, antibacterial and anti-inflammatory effects (Fig. 20B), mainly ophiopolines, biphenyl derivatives, and alkaloids, respectively (Fig. 21 A-C). Moreover, other bioactivities also have been exhibited by diverse metabolites such as antidiabetic, antiviral, anti-oxidant, antifungal, neuroprotective, antimycobacterial activities, in particular, those belong to the butenolides, xanthones, biphenyl derivatives, diterpenes, echinulin-related indole-diketopiperazine alkaloids, steroids class of compounds, respectively as predominant bioactive classes (Fig. 21D and Fig. 22 and 23).

The potentially major and most prevalent pathway to drug development from the marine-derived Aspergillus is the based cultivation in which the given strains are fermented and the metabolites produced are then recovered. Because of special requirements, which are needed not only for fungal growth but also for the production of secondary metabolites, comprehensive effort is concerned with this approach. Moreover, this cultivation-dependent approach is not capable of unlocking the full biosynthetic ability of certain fungi.

In conclusion, the endless need for new bioactive principles is of substantial importance. Marine-derived Aspergillus species have a worthy agenda for novel biologically active compounds discovery, and for this reason, these species are recognized as a productive source of pharmacologically valuable new metabolites. A limitless scope for the discovery of new therapeutic lead scaffolds is thus strongly advocated in the future for the continuous study of marine-derived Aspergillus from underexplored environments.

\section{Conflicts of interest}

The authors declare there is no conflict of interest.

\section{Funding}

Ministry of Education Saudi Arabia funding this work through the project, number IFKSURP-261.

\section{Acknowledgements}

The authors extend their appreciation to the Deputyship for Research \& Innovation, "Ministry of Education" in Saudi Arabia for funding this research work through the project number IFKSURP-261.

\section{References}

1 C. Zhao, H. Liu and W. Zhu, Weishengwu Xuebao, 2016, 56, 331-362.

2 D. W. Blayney, Q. Zhang, J. Feng, Y. Zhao, I. Bondarenko, I. Vynnychenko, N. Kovalenko, S. Nair, E. Ibrahim, D. P. Udovista, R. Mohanlal, S. Ogenstad, E. Ette, L. Du, L. Huang and Y. K. Shi, JAMA Oncol., 2020, 6, 1-8.

3 B. Huggett, Nat. Biotechnol., 2019, 37, 1264-1276.

4 F. Aqil, M. Zahin, K. A. El Sayed, I. Ahmad, K. Y. Orabi and J. M. Arif, Drug Chem. Toxicol., 2011, 34, 167-179.

5 A. M. S. Mayer and K. R. Gustafson, Int. J. Cancer, 2003, 105, 291-299.

6 J. M. Arif, A. A. Al-Hazzani, M. Kunhi and F. Al-Khodairy, J. Biomed. Biotechnol., 2004, 2004, 93-98.

7 B. Haefner, Drug Discovery Today, 2003, 8, 536-544.

8 Y. M. Lee, M. J. Kim, H. Li, P. Zhang, B. Bao, K. J. Lee and J. H. Jung, Mar. Biotechnol., 2013, 15, 499-519.

9 J. Yin, C. Zhang, J. Huang, J. Zhang, D. Liu, J. Huang, P. Proksch and W. Lin, Tetrahedron Lett., 2018, 59, 31573160.

10 A. K. Vala, B. Sachaniya, D. Dudhagara, H. Z. Panseriya, H. Gosai, R. Rawal and B. P. Dave, Int. J. Biol. Macromol., 2018, 108, 41-46.

11 Z. Wu, D. Li, F. Zeng, Q. Tong, Y. Zheng, J. Liu and Q. Zhou, Phytochemistry, 2018, 156, 159-166.

12 W. Feng, C. Chen, S. Mo, C. Qi, J. Gong, X. Li, Q. Zhou, Y. Zhou, D. Li, Y. Lai, H. Zhu, J. Wang and Y. Zhang, Phytochemistry, 2019, 164, 184-191.

13 K. Sun, G. Zhu, J. Hao, Y. Wang and W. Zhu, Tetrahedron, 2018, 74, 83-87.

14 M. F. Abdelwahab, T. Kurtán, A. Mándi, W. E. G. Müller, M. A. Fouad, M. S. Kamel, Z. Liu, W. Ebrahim, G. Daletos and P. Proksch, Tetrahedron Lett., 2018, 59, 2647-2652.

15 C. Qi, W. Gao, D. Guan, J. Wang and M. Liu, Bioorg. Med. Chem., 2018, 26, 5903-5910.

16 A. M. Elissawy, S. S. Ebada, M. L. Ashour and M. El-neketi, Phytochem. Lett., 2019, 29, 1-5.

17 D. Zhang, W. Yi, H. Ge, Z. Zhang and B. Wu, Nat. Prod. Res., 2019, 1-6.

18 Y. Lin, C. Xie, C. Xing, B. Wang, X. Tian, M. Xia, L. Jia, Y. Pan and X. Yang, Nat. Prod. Res., 2019, 1-5.

19 M. Elsbaey, A. Sallam, M. El-metwally, M. Nagata and C. Tanaka, Chem. Biodiversity, 2019, 16, e1900237.

20 N. D. Luyen, L. M. Huong, T. Thi, H. Ha, L. H. Cuong, D. Thi and H. Yen, Vietnam J. Chem, 2019, 57, 654-660.

21 G. Said, X. Mou, Y. Fang, G. Chen and C. Shao, Chem. Nat. Prod., 2018, 54, 463-465.

22 W. Wang, M. Gao, Z. Luo, Y. Liao, B. Zhang, Z. Shao, F. Li and J. Chen, Nat. Prod. Res., 2019, 33, 3077-3082.

23 Y. Zhang, X. Hou, M. Yu and C. Wang, Chem. Nat. Compd., 2019, 55, 279-282.

24 G. Zhou, X. Chen, X. Zhang, Q. Che, G. Zhang, T. Zhu, Q. Gu and D. Li, J. Nat. Prod., 2020, 83, 8-13.

25 Y. N. Ha, S. Song, B. Orlikova-Boyer, C. Cerella, C. Christov, A. Kijjoa and M. Diederich, Mar. Drugs, 2020, 18, 57. 
26 A. Zhu, M. Y. Yang, Y. H. Zhang, C. L. Shao, C. Y. Wang, L. D. Hu, F. Cao and H. J. Zhu, Sci. Rep., 2018, 8, 1-10.

27 S. S. Afiyatullov, O. I. Zhuravleva, A. S. Antonov, D. V. Berdyshev, M. V. Pivkin, V. A. Denisenko, R. S. Popov, A. V. Gerasimenko, G. von Amsberg, S. A. Dyshlovoy, E. V. Leshchenko and A. N. Yurchenko, J. Antibiot., 2018, 71, 846-853.

28 R. Zhou, X. Liao, H. Li, J. Li, P. Feng, B. X. Zhao and S. Xu, Front. Chem., 2018, 6, 1-7.

29 H. J. Shin, B. K. Choi, P. T. H. Trinh, H. S. Lee, J. S. Kang, T. T. T. Van, H. S. Lee, J. S. Lee, Y. J. Lee and J. Lee, Mar. Drugs, 2018, 16(1), 14.

30 S. Buttachon, A. A. Ramos, Â. Inácio, T. Dethoup, L. Gales, M. Lee, P. M. Costa, A. M. S. Silva, N. Sekeroglu, E. Rocha, M. M. M. Pinto, J. A. Pereira and A. Kijjoa, Mar. Drugs, 2018, 16, 1-22.

31 G. Yu, G. Wu, Z. Sun, X. Zhang, Q. Che, Q. Gu, T. Zhu, D. Li and G. Zhang, Mar. Drugs, 2018, 16, 14.

32 X. Li, W. Ding, P. Wang and J. Xu, Mar. Drugs, 2018, 16, 343.

33 Y. N. Wang, Y. H. Mou, Y. Dong, Y. Wu, B. Y. Liu, J. Bai, D. J. Yan, L. Zhang, D. Q. Feng, Y. H. Pei and Y. C. Hu, Mar. Drugs, 2018, 16, 451.

34 M. Frank, F. Can Özkaya, W. E. G. Müller, A. Hamacher, M. U. Kassack, W. Lin, Z. Liu and P. Proksch, Mar. Drugs, 2019, 17, 99.

35 B. K. Choi, P. T. H. Trinh, H. S. Lee, B. W. Choi, J. S. Kang, N. T. D. Ngoc, T. T. T. Van and H. J. Shin, Mar. Drugs, 2019, 17, 349.

36 Y. Fan, Y. Zhou, Y. Du, Y. Wang, P. Fu and W. Zhu, Mar. Drugs, 2019, 17, 400.

37 F. Malhão, A. A. Ramos, S. Buttachon, T. Dethoup, A. Kijjoa and E. Rocha, Mar. Drugs, 2019, 17, 448.

38 Y.-F. Liu, Y.-F. Yue, L.-X. Feng, H.-J. Zhu and F. Cao, Mar. Drugs, 2019, 17, 550-560.

39 Z. X. Li, X. F. Wang, G. W. Ren, X. L. Yuan, N. Deng, G. X. Ji, W. Li and P. Zhang, Molecules, 2018, 23, 2368.

40 Y. Tan, B. Yang, X. Lin, X. Luo, X. Pang, L. Tang, Y. Liu, X. Li and X. Zhou, J. Nat. Prod., 2018, 81, 92-97.

41 G. Wu, X. Qi, X. Mo, G. Yu, Q. Wang, T. Zhu, Q. Gu, M. Liu, J. Li and D. Li, Eur. J. Med. Chem., 2018, 148, 268-278.

42 T. Zhu, Z. Lu, J. Fan, L. Wang, G. Zhu, Y. Wang, X. Li, K. Hong, P. Piyachaturawat, A. Chairoungdua and W. Zhu, J. Nat. Prod., 2018, 81, 2-9.

43 X. Du, D. Liu, J. Huang, C. Zhang, P. Proksch and W. Lin, Fitoterapia, 2018, 130, 190-197.

44 A. S. Antonov, E. V Leshchenko, O. I. Zhuravleva, A. Sergey, G. Von Amsberg, R. S. Popov, V. A. Denisenko, N. N. Kirichuk, S. S. Afiyatullov, G. Von Amsberg, R. S. Popov, V. A. Denisenko and N. N. Kirichuk, Nat. Prod. Res., 2019, 1-4.

45 D. H. Li, T. Han, L. P. Guan, J. Bai, N. Zhao, Z. L. Li, X. Wu and H. M. Hua, Nat. Prod. Res., 2016, 30, 1116-1122.

46 P. K. S. Uchoa, A. T. A. Pimenta, R. Braz-Filho, M. da C. F. de Oliveira, N. N. Saraiva, B. S. F. Rodrigues, L. H. Pfenning, L. M. Abreu, D. V. Wilke, K. G. D. Florêncio and M. A. S. Lima, Nat. Prod. Res., 2017, 31, 2599-2603.
47 X. D. Li, X. Li, X. M. Li, G. M. Xu, P. Zhang, L. H. Meng and B. G. Wang, Planta Med., 2016, 82, 877-881.

48 P. K. S. Uchoa, A. T. A. Pimenta, R. Braz-filho, C. F. De Oliveira, N. N. Saraiva and B. S. F. Rodrigues, Nat. Prod. Res., 2017, 31, 2599-2603.

49 M. M. Lotfy, H. M. Hassan, M. H. Hetta, A. O. El-gendy and R. Mohammed, Beni-Suef Univ. J. Basic Appl. Sci., 2018, 7, 263-269.

50 J. Lin, X. Jiang, X. Liu, C. He, Y. Di, S. Lu, H. Huang, B. Lin, D. Wang and B. Fan, Fitoterapia, 2019, 133, 1-4.

51 P. Xu, L. Ding, J. Wei, Q. Li, M. Gui, X. He, D. Su and S. He, Aquaculture, 2019, 734670.

52 A. N. Shehata, A. A. Abd El Aty, D. A. Darwish, W. A. Abdel Wahab and F. A. Mostafa, Int. J. Biol. Macromol., 2018, 107, 990-999.

53 S. Yang, X. Li, X. Li, H. Li, L. Meng and B. Wang, Phytochem. Lett., 2018, 25, 191-195.

54 H. Li, X. Li, X. Li, S. Yang and B. Wang, Phytochem. Lett., 2019, 32, 138-142.

55 Q. Song, X. Li, X. Hu, X. Li, L. Chi, H. Li and B. Wang, Phytochem. Lett., 2019, 34, 30-34.

56 X. Li, X. Li, X. Li, X. Yin and B. Wang, Nat. Prod. Res., 2019, $1-7$.

57 P. Corral, F. P. Esposito, P. Tedesco, A. Falco, E. Tortorella, L. Tartaglione, C. Festa, M. V. D. Auria, G. Gnavi, G. C. Varese and D. De Pascale, Mar. Biotechnol., 2018, 20, 502-511.

58 L. Guo, F. Zhang, X. Wang, H. Chen, Q. Wang, J. Guo, X. Cao and L. Wang, 3 Biotech, 2019, 9, 1-7.

59 Y. Ji, W. Chen, T. Shan, B. Sun, P. Yan and W. Jiang, Chem. Biodiversity, 2020, 17, e1900640.

60 X. Peng, Y. Wang, T. Zhu and W. Zhu, Arch. Pharmacal Res., 2018, 41, 184-191.

61 Z. Fei, K. Fan-dong, M. Qing-yun, X. Qing-yi, Z. Li-man, Z. You-xing and G. Lei, J. Asian Nat. Prod. Res., 2019, 1-7.

62 G. Said, X. Hou, X. Liu and R. Chao, Chem. Nat. Compd., 2019, 55, 457-459.

63 S. Q. Yang, X. M. Li, X. Li, L. P. Chi and B. G. Wang, Mar. Drugs, 2018, 16, 114.

64 A. Zhu, X. W. Zhang, M. Zhang, W. Li, Z. Y. Ma, H. J. Zhu and F. Cao, Mar. Drugs, 2018, 16, 312.

65 C. L. An, F. D. Kong, Q. Y. Ma, Q. Y. Xie, J. Z. Yuan, L. M. Zhou, H. F. Dai, Z. F. Yu and Y. X. Zhao, Mar. Drugs, 2018, 17, 468.

66 W. Liu, L. Wang, B. Wang, Y. Xu, G. Zhu, M. Lan, W. Zhu and K. Sun, Mar. Drugs, 2019, 17, 6.

67 X. Xu, J. Han, Y. Wang, R. Lin, H. Yang, J. Li, S. Wei, S. W. Polyak and F. Song, Mar. Drugs, 2019, 17, 289.

68 S. Limbadri, X. Luo, X. Lin, S. Liao, J. Wang, X. Zhou, B. Yang and Y. Liu, Molecules, 2018, 23, 2379.

69 Y.-J. Liu, J.-L. Zhang, C. Li, X.-G. Mu, X.-L. Liu, Y.-C. Zhao, P. Zhang, X.-D. Li and X.-X. Zhang, Molecules, 2019, 24, 4596.

70 W. Wang, R. Chen, Z. Luo, W. Wang and J. Chen, Nat. Prod. Res., 2018, 32, 558-563.

$71 \mathrm{X} . \mathrm{Xu}, \mathrm{H}$. Yang, H. Xu, L. Yin, Z. Chen and H. Shen, Nat. Prod. Res., 2018, 32, 821-825. 
72 M. Fredimoses, X. Zhou, W. Ai and X. Tian, Nat. Prod. Res., 2015, 29, 158-162.

73 X. Li, X. Li, X. Li, G. Xu, Y. Liu and B. Wang, Mar. Drugs, 2018, 16, 440.

74 W. Wang, R. Chen, Z. Luo, W. Wang, J. Chen, W. Wang, R. Chen, Z. Luo, W. Wang and J. Chen, Nat. Prod. Res., 2018, 32, 558-563.

75 M. Chena, K.-L. Wanga, M. Liua, Z.-G. Sheb and C.-Y. Wang, Chem. Biodiversity, 2015, 12, 1398-1406.

76 J. Liu, W. Wu, M. Cao, F. Yang and H. Lin, Nat. Prod. Res., 2018, 32, 1791-1797.

77 Z. Liu, Z. Dong, P. Qiu, Q. Wang, J. Yan and Y. Lu, Steroids, 2018, 140, 32-38.

78 G. Liao, P. Wu, J. Xue, L. Liu, H. Li and X. Wei, Fitoterapia, 2018, 131, 50-54.

79 H. Cui, Y. Liu, T. Li, Z. Zhang, M. Ding, Y. Long and Z. She, Fitoterapia, 2018, 124, 177-181.

80 K. Kim, H. Jin, J. Hak, J. Han, Y. Kim and H. Oh, Neurochem. Int., 2018, 113, 8-22.

81 Y. Y. Zhang, Y. Zhang, Y. B. Yao, X. L. Lei and Z. J. Qian, Mar. Drugs, 2018, 16, 202.

82 J. T. Liu, W. Wu, M. J. Cao, F. Yang and H. W. Lin, Nat. Prod. Res., 2018, 32, 1791-1797.

83 B. Bin Gu, W. Wu, F. R. Jiao, W. H. Jiao, L. Li, F. Sun, S. P. Wang, F. Yang and H. W. Lin, Org. Lett., 2018, 20, 7957-7960.

84 M. Liu, W. Sun, J. Wang, Y. He, J. Zhang and F. Li, Bioorg. Chem., 2018, 80, 525-530.

85 Y. Tang, Y. Liu, Q. Ruan, M. Zhao, Z. Zhao and H. Cui, Org. Lett., 2019, 22, 1336-1339.

86 B. Bin Gu, F. R. Jiao, W. Wu, W. H. Jiao, L. Li, F. Sun, S. P. Wang, F. Yang and H. W. Lin, J. Nat. Prod., 2018, 81, 2275-2281.

87 H. Li, W. Sun, M. Deng, Q. Zhou, J. Wang, J. Liu, C. Chen, C. Qi, Z. Luo, Y. Xue, H. Zhu and Y. Zhang, J. Org. Chem., 2018, 83, 8483-8492.

88 M. You, L. Liao, S. H. Hong, W. Park, D. I. Kwon, J. Lee, M. Noh, D. Oh, K. Oh and J. Shin, Mar. Drugs, 2015, 13, 1290-1303.

89 C. Wang, L. Guo, J. Hao, L. Wang and W. Zhu, J. Nat. Prod., 2016, 79, 2977-2981.

90 K. H. Cho, J. H. Sohn and H. Oh, Nat. Prod. Res., 2018, 32, 214-221.

91 D. Kim, T. M. Ha, J. H. Sohn and J. H. Yim, Nat. Prod. Res., 2018, 1-8.

92 Y. Sun, J. Liu, L. Li, C. Gong, S. Wang, F. Yang, H. Hua and H. Lin, Bioorg. Med. Chem. Lett., 2018, 28, 315-318.

93 M. Liu, W. Sun, J. Wang, Y. He, J. Zhang, F. Li, C. Qi, H. Zhu, Y. Xue, Z. Hu and Y. Zhang, Bioorg. Chem., 2018, 80, 525530.

94 Y. Wu, Y. Chen, X. Huang, Y. Pan, Z. Liu, T. Yan, W. Cao and Z. She, Mar. Drugs, 2018, 16, 1-9.

95 Z. Huang, X. Nong, R. Zhe, J. Wang, X. Zhang and S. Qi, Bioorg. Med. Chem. Lett., 2017, 27, 787-791.

96 Y.-Q. Tian, X.-P. Lin, Z. Wang, X.-F. Zhou, X.-C. Qin, K. Kaliyaperumal, T.-Y. Zhang, Z.-C. Tu and Y. Liu, Molecules, 2015, 21, 34.
97 J. Peng, X. Zhang, W. Wang, T. Zhu, Q. Gu and D. Li, Mar. Drugs, 2016, 14, 131.

98 T. Liang, Y. Fang, J. Zheng and C. Shao, Chem. Nat. Compd., 2018, 54, 474-476.

99 H. H. Kang, H. Bin Zhang, M. J. Zhong, L. Y. Ma, D. S. Liu, W. Z. Liu and H. Ren, Mar. Drugs, 2018, 16, 1-9.

100 N. Liu, S. Peng, J. Yang, Z. Cong, X. Lin, S. Liao, B. Yanga, X. Zhoua, X. Zhoub, Y. Liua and J. Wanga, Fitoterapia, 2019, 135, 27-32.

101 A. S. Leutou, K. Yun and B. W. Son, Arch. Pharmacal Res., 2016, 39, 806-810.

102 Z. Wu, Y. Wang, D. Liu, P. Proksch, S. Yu and W. Lin, Tetrahedron, 2016, 72, 50-57.

103 A. Muhammad, L. Xiao, M. Xuan, D. Jun-de and Q. Shuhua, Nat. Prod. Res., 2019, 1-9.

104 Q. Zeng, W. Zhong, Y. Chen, Y. Xiang, X. Chen, W. Zhang, S. Zhang and F. Wang, Nat. Prod. Res., 2019, 1-8.

105 S. Zou, Z. Wang, J. Wang, G. Wei, W. Wang, Y. Zang, F. Zeng, K. Chen, J. Liu, J. Wang, Z. Luo, Y. Xue, H. Zhu, C. Yin, C. Chen and Y. Zhang, Fitoterapia, 2018, 124, 127131.

106 W. U. Ze-hong, L. I. U. Dong, X. U. Ying, C. Jian-liang and L. I. N. Wen-han, Chin. J. Nat. Med., 2018, 16, 219-224.

107 Z. Yang, K. Kaliaperumal, J. Zhang, Y. Liang, C. Guo, J. Zhang, B. Yang and Y. Liu, Nat. Prod. Res., 2020, 1-8.

108 X. D. Li, X. Li, X. M. Li, G. M. Xu, Y. Liu and B. G. Wang, Mar. Drugs, 2018, 16, 440.

109 K. Takahashi, K. Sakai, W. Fukasawa, Y. Nagano, S. O. Sakaguchi, A. O. Lima, V. H. Pellizari, M. Iwatsuki, K. Takishita, T. Yoshida, K. Nonaka, K. Fujikura and S. Ōmura, J. Antibiot., 2018, 71, 741-744.

110 A. N. Yurchenko, O. F. Smetanina, E. V. Ivanets, T. T. Hoai, N. Thi, D. Ngo, O. I. Zhuravleva, A. B. Rasin, A. Sergey, E. S. Menchinskaya, E. A. Pislyagin, G. Von, S. S. Afiyatullov, E. A. Yurchenko, A. N. Yurchenko, O. F. Smetanina, E. V Ivanets, T. Thi, E. S. Menchinskaya, E. A. Pislyagin, G. Von Amsberg and S. S. Afiyatullov, Nat. Prod. Res., 2019, 1-6.

111 E. A. Yurchenko, E. S. Menchinskaya, E. A. Pislyagin, P. T. H. Trinh, E. V. Ivanets, O. F. Smetanina and A. N. Yurchenko, Mar. Drugs, 2018, 16, 457.

112 O. F. Smetanina, A. N. Yurchenko, E. V. G. Ivanets, P. Thi, H. Trinh, A. S. Antonov, S. A. Dyshlovoy, G. Von Amsberg, N. Y. Kim, E. A. Chingizova, E. A. Pislyagin, E. S. Menchinskaya, E. A. Yurchenko, T. T. T. Van and S. S. Afiyatullo, Molecules, 2020, 25, 61.

113 L. U. O. Xiao-wei, L. I. N. Yun, L. U. Yong-jun, Z. Xue-feng and L. I. U. Yong-hong, Chin. J. Nat. Med., 2019, 17, 149154.

114 X. Li, Z. Xia, J. Tang, J. Wu, J. Tong, M. Li, J. Ju, H. Chen and L. Wang, Molecules, 2017, 22, 1302.

115 G. F. A. Lzd-, Z. Cheng, L. Lou, D. Liu, X. Li, P. Proksch, S. Yin and W. Lin, J. Nat. Prod., 2016, 79, 2941-2952.

116 G. K. Oleinikova, O. I. Zhuravleva, D. V Berdyshev, I. Natalia, R. S. Popov, V. A. Denisenko, N. N. Kirichuk and S. S. Afiyatullov, Nat. Prod. Res., 2019, 1-4. 
117 A. Ls, L. Huang, L. Ding, X. Li, N. Wang, Y. Yan, M. Yang, W. Cui, C. B. Naman, K. Cheng, W. Zhang, B. Zhang, H. Jin, L. Dak, S. Yip, Y. Chin and K. Li, Bioorg. Med. Chem. Lett., 2019, 29, 1593-1596.

118 W. C. Yang, H. Y. Bao, Y. Y. Liu, Y. Y. Nie, J. M. Yang, P. Z. Hong and Y. Zhang, Molecules, 2018, 23, 2245.
119 S. Lima, A. Mendes, G. Franco, A. Ferreira, D. Silva, I. Evódio and J. Aparecida, Phytochem. Lett., 2018, 24, 39-45. 120 S. K. Shanuja, S. Iswarya and A. Gnanamani, J. Photochem. Photobiol., B, 2018, 179, 139-148. 